ARTICLE

https://doi.org/10.1038/s41467-019-09212-y

\title{
NKG2A is a NK cell exhaustion checkpoint for HCV persistence
}

Chao Zhang ${ }^{1,2}$, Xiao-mei Wang ${ }^{3}$, Shu-ran Li, ${ }^{1,2,4}$, Trix Twelkmeyer ${ }^{1,5}$, Wei-hong Wang ${ }^{1,2,4}$, Sheng-yuan Zhang ${ }^{1,2,6}$, Shu-feng Wang ${ }^{7}$, Ji-zheng Chen ${ }^{8}$, Xia Jin ${ }^{5}$, Yu-zhang Wu ${ }^{7}$, Xin-wen Chen ${ }^{8}$, Sheng-dian Wang ${ }^{2}$, Jun-qi Niu ${ }^{3}$, Hai-rong Chen ${ }^{1,2} \&$ Hong Tang ${ }^{1,5,8}$

Exhaustion of cytotoxic effector natural killer (NK) and CD8 $+\mathrm{T}$ cells have important functions in the establishment of persistent viral infections, but how exhaustion is induced during chronic hepatitis $\mathrm{C}$ virus ( $\mathrm{HCV}$ ) infection remains poorly defined. Here we show, using the humanized $\mathrm{C} / \mathrm{O}^{\mathrm{Tg}}$ mice permissive for persistent $\mathrm{HCV}$ infection, that $\mathrm{NK}$ and $\mathrm{CD} 8^{+} \mathrm{T}$ cells become sequentially exhausted shortly after their transient hepatic infiltration and activation in acute HCV infection. HCV infection upregulates Qa-1 expression in hepatocytes, which ligates NKG2A to induce NK cell exhaustion. Antibodies targeting NKG2A or Qa-1 prevents NK exhaustion and promotes NK-dependent HCV clearance. Moreover, reactivated NK cells provide sufficient IFN- $\gamma$ that helps rejuvenate polyclonal $\mathrm{HCV} \mathrm{CD8}{ }^{+} \mathrm{T}$ cell response and clearance of HCV. Our data thus show that NKG2A serves as a critical checkpoint for HCVinduced NK exhaustion, and that NKG2A blockade sequentially boosts interdependent NK and $\mathrm{CD}^{+}{ }^{+} \mathrm{T}$ cell functions to prevent persistent $\mathrm{HCV}$ infection.

\footnotetext{
${ }^{1}$ The Joint Laboratory of Infection and Immunity at Institut Pasteur of Shanghai and Institute of Biophysics, Chinese Academy of Sciences, Beijing 100101, China. ${ }^{2}$ The Key Laboratory of Infection and Immunity, Institute of Biophysics, Chinese Academy of Sciences, 100101 Beijing, China. ${ }^{3}$ Department of Hepatology, The First Hospital of Jilin University, 130021 Changchun, Jilin, China. ${ }^{4}$ College of Life Sciences, University of Chinese Academy of Sciences, 100049 Beijing, China. ${ }^{5}$ The Key Laboratory of Molecular Virology and Immunology, Institut Pasteur of Shanghai, Chinese Academy of Sciences, 200031 Shanghai, China. ${ }^{6}$ School of Life Science and Technology, ShanghaiTech University, 200031 Shanghai, China. ${ }^{7}$ Institute of Immunology, The Third Military Medical University, 400038 Chongqing, China. ${ }^{8}$ The State Key Laboratory of Virology and Center for Viral Pathology, Wuhan Institute of Virology, Chinese Academy of Sciences, 430071 Wuhan, China. These authors contributed equally: Chao Zhang, Xiao-mei Wang. Correspondence and requests for materials should be addressed to H.-r.C. (email: hairong.chen@ibp.ac.cn) or to H.T. (email: htang@ips.ac.cn)
} 
epatitis $\mathrm{C}$ virus (HCV) infection causes more than 185 million carriers worldwide ${ }^{1}$. During the natural course of $\mathrm{HCV}$ infection, spontaneous clearance of the virus occurs in only $15-20 \%$ of acutely infected adults, while the remainders develop chronic infection, which often progress to cirrhosis and hepatocellular carcinoma ${ }^{2}$. Exhaustion of $\mathrm{HCV}$-specific $\mathrm{CD}^{+}$ $\mathrm{T}$ cells, characterized by upregulation of co-inhibitory receptors (PD-1, CTLA-4, Tim-3, Lag-3, 2B4, and CD160), may associate with chronic hepatitis $\mathrm{C}(\mathrm{CHC})^{3}$, with $\mathrm{PD}-1$ being the most studied. However, PD-1 checkpoint inhibitor therapy only induce fairly limited antiviral response in $\mathrm{HCV}$-infected primates $(1 \text { of } 3)^{4}$ or patients $(4 \text { of } 20)^{5}$. In agreement with this, PD-1 blockade in vitro is insufficient to restore the cytotoxicity of hepatic CD8 ${ }^{+}$ $\mathrm{T}$ cells isolated from CHC patients ${ }^{6,7}$. Thus, more roadblocks of immune tolerance need to be removed in $\mathrm{CHC}$ in addition to $\mathrm{PD}-1$ or cytotoxic $\mathrm{CD}^{+} \mathrm{T}$ lymphocytes (CTL).

Natural killer (NK) cells are an important effector lymphocyte population in anti-tumor and anti-infection immunity ${ }^{8}$. NK cells account for $25-50 \%$ of human liver lymphocytes and $5-10 \%$ of mouse liver lymphocytes ${ }^{9}$, indicating their importance in livers. The activity of NK cells is controlled by an array of activating and inhibitory receptors ${ }^{10}$. A number of studies have highlighted the potential importance of NK cells during HCV infection ${ }^{11}$. In brief, NK cells are activated in the acute phase of HCV infection, with upregulation of the activating receptors (e.g., NKG2D), IFN- $\gamma$ production and cytotoxicity ${ }^{12}$, which associates with the spontaneous clearance of HCV in healthcare workers ${ }^{13}$ and intravenous drug users ${ }^{14}$. On the other hand, chronic HCV infection often associates with exhaustion of NK cells, limiting its antiinfection activity. For example, the inhibitory receptor NKG2A is upregulated in the circulating NK cells ${ }^{15}$, in line with the reduced IFN- $\gamma$ production ${ }^{16}$ and cytotoxic function ${ }^{16,17}$ of intrahepatic $\mathrm{NK}$ cells in $\mathrm{CHC}$ patients. Another NK inhibitory receptor, KIR2DL3, when present on a homozygous ligand background (HLA-C1/C1) that induces a weaker inhibitory effect easier to be overcome by activation signals, is associated with spontaneous resolution of $\mathrm{HCV}$ infection ${ }^{18}$. However, how NK cell exhaustion is induced and maintained early in the infection, and more importantly, whether NK cell exhaustion determines HCV persistence, remain unclear.

By expressing human occludin and CD81 in an outbred ICR strain $\left(\mathrm{C} / \mathrm{O}^{\mathrm{Tg}}\right)$, we have previously generated an immunecompetent humanized mouse permissive for $\mathrm{HCV}$ persistent infection ${ }^{19}$, and have successfully applied to a number of studies ${ }^{19-23}$. Using this mouse model, we show here the dynamics of hepatic infiltration and exhaustion of $\mathrm{NK}$ and $\mathrm{CD}^{+} \mathrm{T}$ cells during acute $\mathrm{HCV}$ infection. Furthermore, we are able to depict the nature of upregulated hepatic Qa-1 interacting with the inhibitory receptor NKG2A on NK cells to induce NK exhaustion. Anti-Qa-1 or anti-NKG2A antibody treatment restores NK and sequentially $\mathrm{CD}^{+} \mathrm{T}$ cell cytotoxicities in $\mathrm{HCV}$ clearance. Our study highlights the importance of Qa-1/NKG2A exhaustion checkpoint, when compared with PD-1/Tim-3, in the establishment of $\mathrm{HCV}$ persistence.

\section{Results}

HCV persistence is associated with $\mathrm{CD8}^{+} \mathrm{T}$ cell exhaustion. Acute HCV infection is characterized by a significant delay in the onset of $\mathrm{T}$ cell response ${ }^{24}$. We have shown previously that hepatic infiltrated T cells were generally inactive after HCV infection ${ }^{19}$. Using the same humanized mice model of persistent $\mathrm{HCV}$ infection, we repeated the tail vein perfusion of $\mathrm{C} / \mathrm{O}^{\mathrm{Tg}}$ mice or $\mathrm{wt}$ littermates with HCV. Measurement of HCV genome copies in livers indicated the expected progression of acute $(1 \mathrm{~d}-2 \mathrm{w})$ to persistent $(>2 \mathrm{w})$ infection (Fig. 1a). Luminex measurement of serum cytokines showed the typical delayed Th1 (IFN- $\gamma$, IL-2, and IL-12p40) and an absence of Th2 response (type II cytokines below detection limits) along the course of infection (Supplementary Fig. $1 \mathrm{~A}$ and $\mathrm{B}$ ), reminiscent of the observation in patients $^{25}$.

We then assessed $\mathrm{HCV}$-specific $\mathrm{CD} 8^{+} \mathrm{T}$ cell response. ELISpot analysis on splenocytes isolated from wt or $\mathrm{C} / \mathrm{O}^{\mathrm{Tg}}$ mice showed that HCV multi-specific $\mathrm{T}$ cells were elevated preferentially in $\mathrm{HCV}$ (genotype $2 \mathrm{a}$ ) infected $\mathrm{C} / \mathrm{O}^{\mathrm{Tg}}$ mice, which peaked at 4-7 dpi (see Table S1 for HCV NS3, NS5B, NS5A, and core peptides), and vanished at 2 wpi (Fig. 1b). Striking enough, the decline of HCV-specific T cell response was concomitant with upregulation of PD-1 in both hepatic and peripheral CD8 ${ }^{+} \mathrm{T}$ cells (Fig. 1c). To exclude artifacts caused by a particular HCV strain, ELISpot assays were performed after $\mathrm{C} / \mathrm{O}^{\mathrm{Tg}}$ mice were infected with patient sera positive for $\mathrm{HCV} 1 \mathrm{~b}\left(3.93 \times 10^{6}\right.$ copies $\left./ \mathrm{mL}\right)$. Persistent $\mathrm{HCV} 1 \mathrm{~b}$ infection in $\mathrm{C} / \mathrm{O}^{\mathrm{Tg}}$ liver (Supplementary Fig. 2A) correlated with HCV multi-specific T cell exhaustion (Supplementary Fig. 2B; see Table S2 for HCV epitope pools) and PD-1 upregulation in $\mathrm{CD}^{+}$and $\mathrm{CD}^{+} \mathrm{T}$ cells, starting at 1 wpi (Supplementary Fig. 2C). Of note, PD-1 upregulation was faster and more pronounced in hepatic $\mathrm{CD}^{+} \mathrm{T}$ cells than peripheral $\mathrm{CD}^{+} \mathrm{T}$ cells (Fig. 1c and Supplementary Fig. 2C). Taken together, these results suggest that $\mathrm{CD}^{+} \mathrm{T}$ cell exhaustion concurred with $\mathrm{HCV}$ persistent infection in $\mathrm{C} / \mathrm{O}^{\mathrm{Tg}}$ mice, reminiscent to $\mathrm{CHC}$ patients ${ }^{26}$

Previous studies with PBMC of CHC patients showed PD-L1/ $\mathrm{PD}-1$ upregulation associated with $\mathrm{HCV}$-specific $\mathrm{T}$ cell exhaustion $^{27}$. We further showed that PD-L1 was increased in $\mathrm{C} / \mathrm{O}^{\mathrm{Tg}}$ hepatocytes 2 wpi (Fig. 1d), presumably by the transient activation of type I or II IFNs upon HCV invasion ${ }^{28}$. To substantiate whether PD-L1/PD-1 signaling was critically involved in establishment and/or maintenance of $\mathrm{CD}^{+} \mathrm{T}$ cell exhaustion, PD-1 blocking antibody was i.p. administrated to $\mathrm{C} /$ $\mathrm{O}^{\mathrm{Tg}}$ mice 1 day before $\mathrm{HCV}$ inoculation and continued for 2 or 4 weeks (Fig. 1e). The results indicated that PD-1 intervention slightly reduced viral loads in the serum but not liver at 2 wpi, and a prolonged treatment had no benefit (Fig. 1f). Failure to clear HCV by PD-1 inhibitor was associated with negligible change of HCV-specific T cell activities (Fig. 1g). Recent in vitro studies suggest that a combined blockade of PD- 1 and CTLA- ${ }^{6}$ or Tim- $3^{29}$ can reactivate HCV-specific $\mathrm{CD}^{+} \mathrm{T}$ cells. Tim- 3 was also upregulated in intrahepatic $\mathrm{CD}^{+} \mathrm{T}$ cells of $\mathrm{HCV}$-infected $\mathrm{C} /$ $\mathrm{O}^{\mathrm{Tg}}$ mice (Fig. 1h). However, a dual administration of blocking antibodies to PD-1 and Tim-3 failed to reduce HCV loads in C/ $\mathrm{O}^{\mathrm{Tg}}$ mice (Fig. 1i). Therefore, PD-1/Tim-3 blockade was insufficient to reverse $\mathrm{CD} 8^{+} \mathrm{T}$ cell exhaustion, or alternatively, more blocks of immune tolerance, dependent or independent of $\mathrm{T}$ cell exhaustion in livers, needs to be overcome to eliminate HCV.

Impaired hepatic NK cell function leads to $\mathrm{HCV}$ persistence. Restricted by availability and accessibility to liver tissues of patients with acute infection, the role of intrahepatic NK cells in the establishment of HCV persistence remains largely speculative. We previously showed that NK cells, but not NKT or other myeloid cells, were recruited to the liver $12 \mathrm{~h}$ post $\mathrm{HCV}$ infection in $\mathrm{C} / \mathrm{O}^{\mathrm{Tg}}$ mice $^{19}$. Interestingly, the acute liver infiltration of $\mathrm{NK}$ cells coincided perfectly with the sharp elevation of chemokines known for NK cell chemotaxis (MCP-1/CCL2, KC/CXCL1, MIG/ CXCL9, and IP-10/ CXCL10) within 2 dpi (Supplementary Fig. 1C). For hepatic non-parenchymal cells (NPC) isolated from the same set of mice in Fig. 1a, we examined the phenotypic profile of $\mathrm{NK}$ cell functions. Only in infected $\mathrm{C} / \mathrm{O}^{\mathrm{Tg}}$ but not abortively infected wt mice, circulating cytokines responsible for NK differentiation (IL-12p40; Supplementary Fig. 1A) and NK 

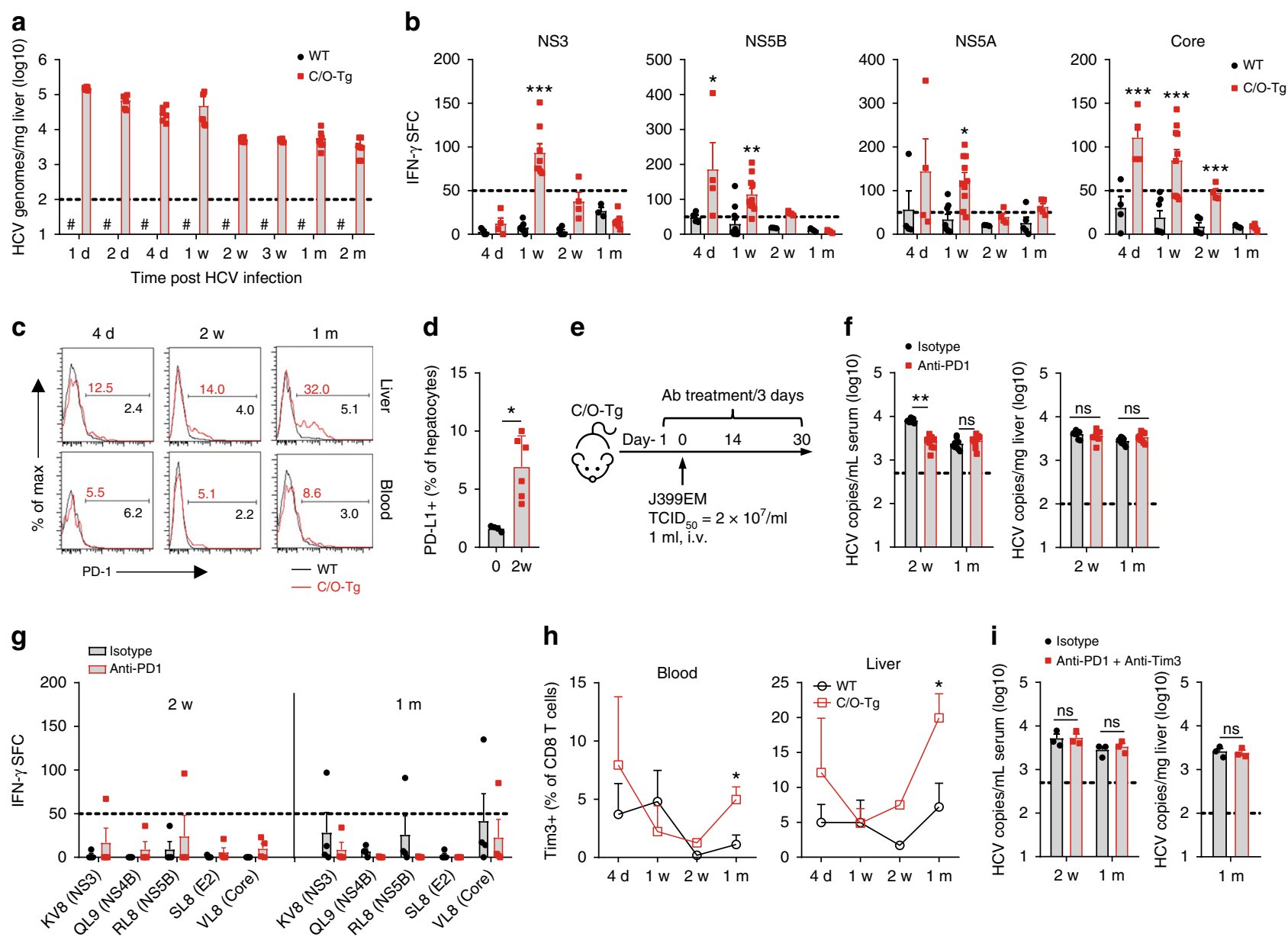

Fig. $1 \mathrm{CD}^{+} \mathrm{T}$ cell exhaustion and PD-1 blockade. $\mathrm{C} / \mathrm{O}^{\top \mathrm{g}}(n=55, n \geq 6$ for each time point) or wt mice $(n=32, n=4$ for each time point) were i.v. infused with $\left.1 \mathrm{~mL} \mathrm{HCV} \mathrm{J399EM} \mathrm{(TCID} 50=2 \times 10^{7} / \mathrm{mL}\right)$. Mice were killed and blood, splenocytes, hepatocytes, and NPCs were collected at indicated time. a HCV RNA copies in hepatocytes were measured by qPCR. b The number of IFN- $\gamma$ spot-forming cells (SFCs) by ELISpot assay determined $2.5 \mathrm{~d}$ after in vitro stimulation of splenocytes with respective epitope peptides, subtracted the SFC of OVA stimulation as the background. c FACS measurement of PD-1 expression in circulating or hepatic CD8 ${ }^{+} \mathrm{T}$ cells at indicated time post HCV infection. d FACS analysis of PD-L1 expression on hepatocytes isolated from naive $(n=4)$ or $\mathrm{HCV}$-infected C/OTg mice $(n=6) 2$ wpi. e C/OTg mice $(n=9$ for each group) were i.p. injected with PD- 1 blocking antibody or isotype lg (200 $\mu \mathrm{g} / 3$ days) 1 day before HCV inoculation. $\mathbf{f} \mathrm{HCV}$ RNA copies in serum and livers, and $\mathbf{g} \mathrm{HCV}$-specific T cells response to the indicated epitopes. h FACS analysis of Tim-3 expression on peripheral and liver CD8 ${ }^{+}$T cells. $\mathbf{i}$ qPCR measurement of HCV RNA copies in the liver or blood after C/O ${ }^{T g}$ mice ( $n=3$ for each group) were i.p. injected with PD-1 (200 $\mu \mathrm{g} / 3$ days) plus Tim-3 (100 $\mu \mathrm{g} / 2$ days) blocking antibody or isotype lgG 1 day before HCV inoculation. Dash lines indicated limits of detection of related assays (qPCR: 100 copies $/ \mathrm{mg}$ liver, 500 copies $/ \mathrm{mL}$ serum; ELISpot: 50 spots $/ 4 \times 10^{5}$ splenocytes). \#, below detection limit. Data were mean \pm SD, Student $t$-test in $\mathbf{b}, \mathbf{d}, \mathbf{f}, \mathbf{h}$, and $\mathbf{i} .{ }^{\star} P<0.05$; ${ }^{\star \star} P<0.01$; ${ }^{\star \star \star} P<0.001$. ns Not significant. Source data are provided as a Source Data file

function (IFN- $\gamma$, RANTES/CCL5; Supplementary Fig. 1B) peaked in the first two days and quickly declined to the baseline within 4 dpi. FACS analysis of NPC confirmed an increase of the conventional DX5 ${ }^{+}$NK subset (Fig. 2a) and homologous functional $\mathrm{CD}_{11 \mathrm{~b}^{+}}$population (Fig. $2 \mathrm{~b}$ ) within $4 \mathrm{dpi}$ (see Supplementary Fig. 3 for gating strategy), which concurred well with upregulation of NK activating receptors, Ly49D, Ly49H, and NKG2D, in $\mathrm{C} / \mathrm{O}^{\mathrm{Tg}}$ mice (Fig. $2 \mathrm{c}$ ). These results suggest a transient hepatic infiltration and activation of $\mathrm{NK}$ cells in response to $\mathrm{HCV}$ infection. More importantly, these activating receptors descended at $4 \mathrm{dpi}$, which yielded to the increase of the inhibitory receptors, KLRG1, NKG2A, and TIGIT in hepatic NK cells, and sustained to 2 mpi (Fig. 2d). Several other inhibitory markers, including Ly49 receptors and Tim-3, were not responsive to $\mathrm{HCV}$ infection (Supplementary Fig. 4). HCV upregulation of NKG2A and KLRG1 was also observed for peripheral NK cells (Fig. 2e). Intrahepatic NK cell exhaustion along the course of HCV infection was then confirmed by NK function assay in vitro. Results showed that intracellular IFN- $\gamma$ and CD107a of NK cells isolated from $\mathrm{C} / \mathrm{O}^{\mathrm{Tg}}$ livers elevated within $4 \mathrm{dpi}$, which rapidly declined to the baseline as the un-infected hepatic NK cells afterwards (Fig. 2f). In parallel, CD107a and granzyme B were also reduced in NK cells when $\mathrm{C} / \mathrm{O}^{\mathrm{Tg}}$ mice progressed to persistent $\mathrm{HCV} 1 \mathrm{~b}$ infection (Supplementary Fig. 2D). Therefore, liver-infiltrated NK cell exhaustion might attribute to $\mathrm{HCV}$ persistent infection in $\mathrm{C} /$ $\mathrm{O}^{\mathrm{Tg}}$ mice.

To delineate which inhibitory receptor(s) accounted for NK cell exhaustion in the liver, we analyzed carefully the cohort of $\mathrm{C} /$ $\mathrm{O}^{\mathrm{Tg}}$ mice with different outcomes of HCV infection (Fig. 3a, b). Mice with spontaneous clearance of HCV exhibited a very low NKG2A expression in peripheral NK cells, whereas $40 \%$ of mice with persistent HCV infection showed a much higher NKG2A level (Fig. 2c). Other receptors (NKG2D and TRAIL; Supplementary Fig. 5A) or functional cytokines (G-CSF, IP-10, MIG, CXCL5; Supplementary Fig. 5B) of NK cells were not differently expressed. PD-1, KLRG1, and Tim-3 receptors in peripheral 

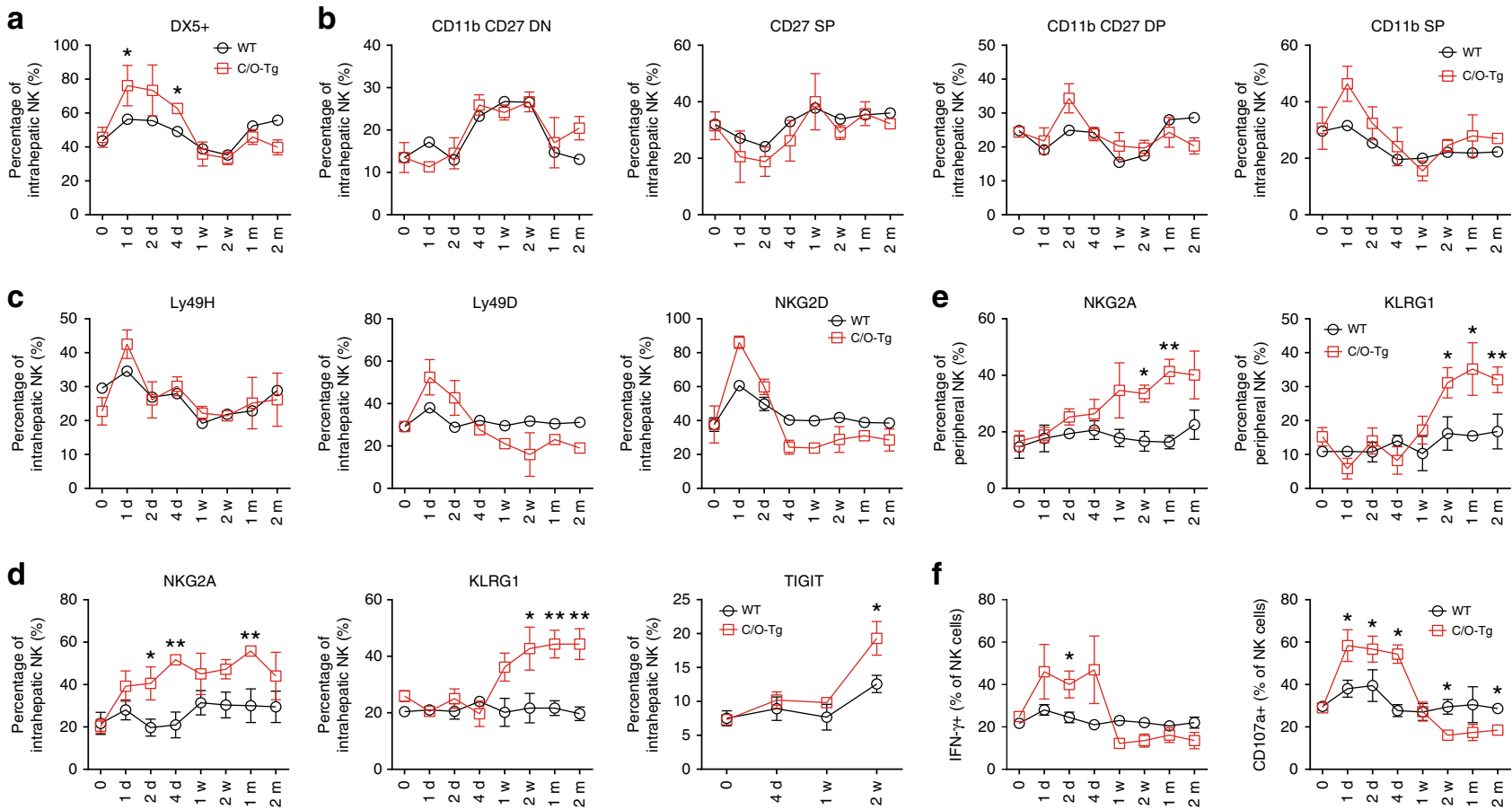

Fig. 2 Impaired hepatic NK cell response during HCV persistent infection in C/O'g mice. Mice were treated as in Fig. 1a. FACS analyses of intrahepatic NK cells for expression of $\mathbf{a}$ DX5, $\mathbf{b}$ CD11b, and CD27, $\mathbf{c}$ activation receptors, including Ly49D, Ly49H, and NKG2D, and $\mathbf{d}$ inhibitory receptors, including NKG2A, KLRG1, and TIGIT. e FACS analyses of peripheral NK cells for expression of NKG2A and KLRG1. $\mathbf{f}$ NK function assays were carried out at indicated time of HCV infection by Yac- 1 cell stimulation. CD107a and IFN- $\gamma$ expression were FACS analyzed. Data were mean \pm SD, ANOVA test. ${ }^{\star} P<0.05$; ${ }^{\star \star} P<$ 0.01. Source data are provided as a Source Data file

$\mathrm{CD}^{+} \mathrm{T}$ cells failed to differentiate self-limiting from persistent infection, either (Supplementary Fig. 5C). Therefore, NKG2A upregulation, potentially impaired NK function, might contribute to the establishment of HCV persistence.

To determine whether NKG2A signaling was required for HCV persistence, a blocking antibody against NKG2A was i.p. administrated 1 day before $\mathrm{HCV}$ infection and continued once every 3 days until 1 or 2 wpi when $\mathrm{C} / \mathrm{O}^{\mathrm{Tg}}$ mice were killed (Fig. 3d). NKG2A blockade resulted in a significant reduction of $\mathrm{HCV}$ replication in livers and the serum at 1 and 2 wpi (Fig. 3e). The reduced HCV replication correlated with the increased NK degranulation (Fig. 3f) and NK killing activities (Fig. 3g) after anti-NKG2A treatment. Therefore, we suspected that NKG2A blockade would benefit a robust clearance of HCV infection from preventing or reversing of NK exhaustion in the liver. To further test whether NKG2A blockade was effective to impede the progression of acute to persistent $\mathrm{HCV}$ infection, anti-NKG2A was employed $2 \mathrm{wpi}$, when the elevated expression of NKG2A had already been observed (Fig. 2d, e), and continued for additional 2 weeks (Fig. 3h). NKG2A inhibition reduced HCV levels in sera and livers (Fig. 3i), accompanied by not only an elevated hepatic NK cell activity (Fig. 3j), but also HCV-specific $\mathrm{T}$ cells response (Fig. 3k). Therefore, in HCV chronic infection, targeting NKG2A would break the immune tolerance of both NK and $\mathrm{HCV}$-specific $\mathrm{T}$ cell response. Of note, anti-NKG2A antibody (clone 20D5) also recognizes NKG2C and NKG2E, two activating receptors of NKG2 family members ${ }^{30}$. However, the effect of the antibody to reverse NK cell exhaustion suggests that NKG2A checkpoint inhibition was the major mechanism involved.

NK and T cells interplay contributes to $\mathrm{HCV}$ persistence. The previous $^{14,31}$ and aforementioned results suggest that an increased NK function positively correlated with the magnitude of virus-specific $\mathrm{T}$ cell responses, and exhaustion of $\mathrm{NK}$ and
T cells would both associate with HCV persistence. It is therefore critical to determine the nature of $\mathrm{NK}$ and $\mathrm{T}$ cells interplay in the course of $\mathrm{HCV}$ infection. Intriguingly, inactivation of NKG2A signaling readily reversed $\mathrm{NK}$ cell exhaustion (Fig. 3g) and reduced $\mathrm{HCV}$ viral loads within 1 wpi (Fig. 3e), when $\mathrm{HCV}$ multi-specific $\mathrm{T}$ cell responses were not fully restored (Fig. 4a). On the other hand, PD-1 blockade failed to restore NK cell function (Supplementary Fig. 6). Therefore, impairment of NK cell function would precede $\mathrm{T}$ cells exhaustion in the establishment of $\mathrm{HCV}$ persistent infection. NKG2A is also expressed in T cells. To substantiate that NKG2A upregulation in NK cells was specifically required for signaling to $\mathrm{T}$ cell exhaustion, we depleted NK cells (Supplementary Fig. 7A for depletion efficacy) prior to anti-NKG2A treatment in $\mathrm{C} / \mathrm{O}^{\mathrm{Tg}}$ mice. The results showed that, in the absence of NK cells, NKG2A blockade failed to restore $\mathrm{HCV}$-specific $\mathrm{T}$ cell activities (Fig. 4b), and with a pronounced elevation of HCV viral loads (Fig. 4c). Restoration of HCV-specific $\mathrm{T}$ cells cytotoxicity by anti-NKG2A would thus depend on NK cells. On the other hand, elimination of HCV by reactivated NK cells after anti-NKG2A treatment requires $\mathrm{CD} 8^{+}$ $\mathrm{T}$ cells. This is because a prior depletion of $\mathrm{CD}^{+} \mathrm{T}$ cells in $\mathrm{C} / \mathrm{O}^{\mathrm{Tg}}$ mice (Supplementary Fig. 7B for depletion efficacy) abolished the effect of anti-NKG2A on HCV replication inhibition (Fig. 4c). Therefore, impairment of NK cell function would lead to CD8 ${ }^{+} \mathrm{T}$ cell exhaustion in the establishment of HCV persistent infection.

HCV upregulated hepatic Qa-1 impairs NK function. HCV virus per se does not affect $\mathrm{NK}$ function ${ }^{32}$, rather that $\mathrm{HCV}$ infected hepatocytes induce functional activation ${ }^{33}$ or impairment of human NK cells ${ }^{34,35}$. These results probably stem from in vitro co-culture of NK cells and HCV-infected cell lines, which are MHC-mismatched, transformed or natural immunogenic to NK cells. To validate the interaction between HCV-infected liver cells and NK cells, we devised a NK function assay by co-culturing the 

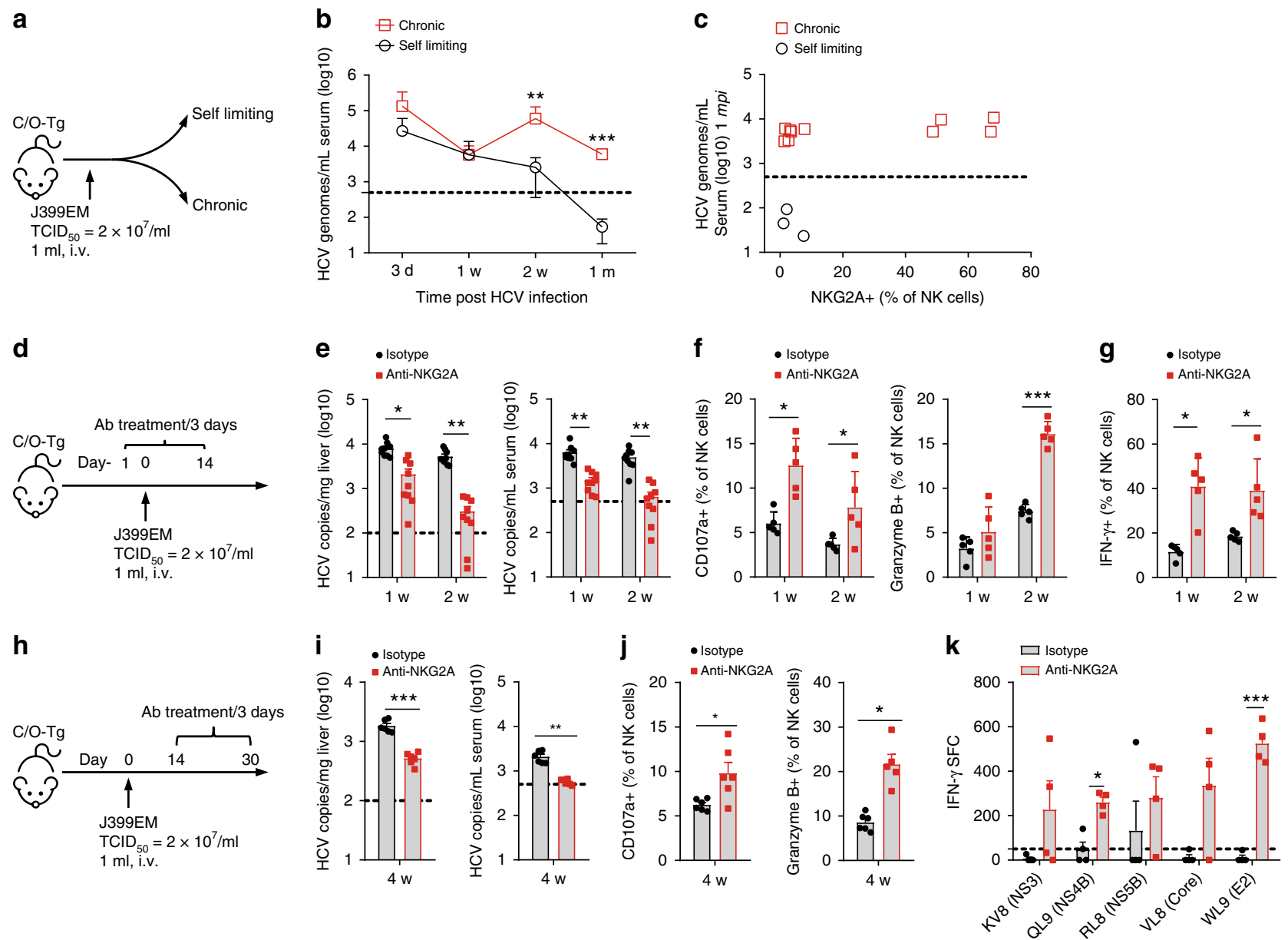

Fig. 3 NKG2A blocking promoted HCV clearance. a C/O ${ }^{T g}$ mice $(n=13)$ were infected with $1 \mathrm{~mL} \mathrm{HCV} \mathrm{J399EM}\left(\mathrm{TCID}_{50}=2 \times 10^{7} / \mathrm{mL}\right) . \mathbf{b}$ The self-limited infection in $\mathrm{C} / \mathrm{O}^{\top \mathrm{g}}$ mice exhibited an initial high peripheral viral load $(<1 \mathrm{mpi}$ ) followed with RNA copies below the detection limit $(\geq 1 \mathrm{mpi})$, whereas $\mathrm{HCV}$ persistent infection was characterized by sustained HCV viral loads in the serum beyond 1 mpi. c FACS analysis of NKG2A in peripheral NK cells and qPCR measurement of HCV RNA copies in the serum $1 \mathrm{~m}$ after $\mathrm{C} / \mathrm{O}^{\top \mathrm{g}}$ mice $(n=13)$ were infected. $\mathbf{d} \mathrm{C} / \mathrm{O}^{\top \mathrm{Tg}}$ mice $(n=9$ for each time point $)$ were treated with anti-NKG2A or isotype lg $(100 \mu \mathrm{g} / 3$ days, i.p.) 1 day before HCV infection. e qPCR measurement of HCV RNA copies in livers and sera; $\mathbf{f}$ FACS analysis of CD107a and granzyme B expression in NK cells; $\mathbf{g}$ FACS analysis of intracellular IFN- $\gamma$ in isolated NK cells after co-cultured with Yac-1. h C/OTg mice $(n=6$ for each time point) were treated with anti-NKG2A or isotype lg (100 $\mu \mathrm{g} / 3$ days, i.p.) beginning at 2 wpi, i HCV RNA copies in livers and sera; $\mathbf{j}$ CD107a and granzyme B were measured in NK cells; and $\mathbf{k} \mathrm{HCV}$-specific CD8 ${ }^{+} \mathrm{T}$ cell response by IFN- $\gamma$ ELISpot assays using splenocytes ( $4 \times 10^{5}$ for each well) isolated from mice $1 \mathrm{mpi}$. Epitope peptides (final concentration $4 \mu \mathrm{g} / \mathrm{mL}$ ) were indicated. Dash lines indicated limits of detection (qPCR, $500 \mathrm{copies} / \mathrm{mL}$ serum or 100 copies/mg liver; ELISpot, 50 spots $/ 4 \times 10^{5}$ splenocytes). Data were mean \pm SD, Student $t$-test. ${ }^{\star} P<0.05 ;{ }^{\star \star} P<0.01 ;{ }^{\star \star \star} P<0.001$. Source data are provided as a Source Data file

isolated NPC or purified NK cells with the matched HCV-infected primary hepatocytes (PHT) (Fig. 5a). C/O Tg PHT were fully supportive of HCV infection (Supplementary Fig. 8A and B), as previously described ${ }^{19}$. The addition of HCV-infected PHT, but not naive PHT, downregulated expression of CD107a and secretion of IFN- $\gamma$ by NK cells, which had been stimulated by Yac-1 target cells or PMA and ionomycin $(\mathrm{P}+\mathrm{I})$ treatment (Fig. 5b). Therefore, $\mathrm{HCV}$-infected hepatocytes impair NK cell function.

How HCV-infected PHT cells impaired NK cell function remains unknown. We previously observed a transient activation of type I/III IFNs and IL-10 in acute $\mathrm{HCV}$ infection of $\mathrm{C} / \mathrm{O}^{\mathrm{Tg}}$ mice $^{19}$. Upregulated PD-L1 and IL-10 in DC and macrophages by type I interferons (IFN) may contribute to T cell exhaustion in the establishment of LCMV viral persistence ${ }^{36,37}$. IL-10 is also shown to upregulate NKG2A in NK cells in chronic HBV infection ${ }^{38}$. To investigate whether these cytokines may modulate $\mathrm{NK}$ cell function in response to $\mathrm{HCV}$ infection, we repeated the assay as in Fig. 5a, in presence of various blocking antibodies as indicated (Fig. 5c). Surprisingly, blockage of NKG2A (anti-
NKG2A) and Qa-1, the ligand of NKG2A in mice, effectively alleviated the functional impairment of NK cells induced by HCV-infected PHT, when compared with isotype antibody control (Fig. 5c). In contrast, antibody blocking of type I/III interferon (anti-IFNaR1 and anti-IL28) or IL-10 (anti-IL10R) signaling failed to do so (Fig. 5c). These results suggest that Qa-1/ NKG2A ligation would be directly involved in functional impairment of hepatic NK cells after $\mathrm{HCV}$ infection. As a control, addition of the supernatant of HCV-infected PHT (CM$\mathrm{PHT}+\mathrm{HCV}$ ) (Fig. 5d) or transwell separation of HCV-infected PHT from NPC (Fig. 5e) no longer inhibited NK killing activities. Therefore, HCV-infected hepatocytes inhibit NK cell function via cell-cell contact manner, most likely through Qa-1/NKG2A interaction. Other NPC cells, such as monocytes, DC, B, or $\mathrm{T}$ cells, were ruled out for their involvement in modulating NK activities by using purified NK cells instead of NPC in the coculture system (Fig. 5e). These results thus indicate that $\mathrm{HCV}$ infection of hepatocytes impairs hepatic NK cells function likely through Qa-1/NKG2A ligation. 


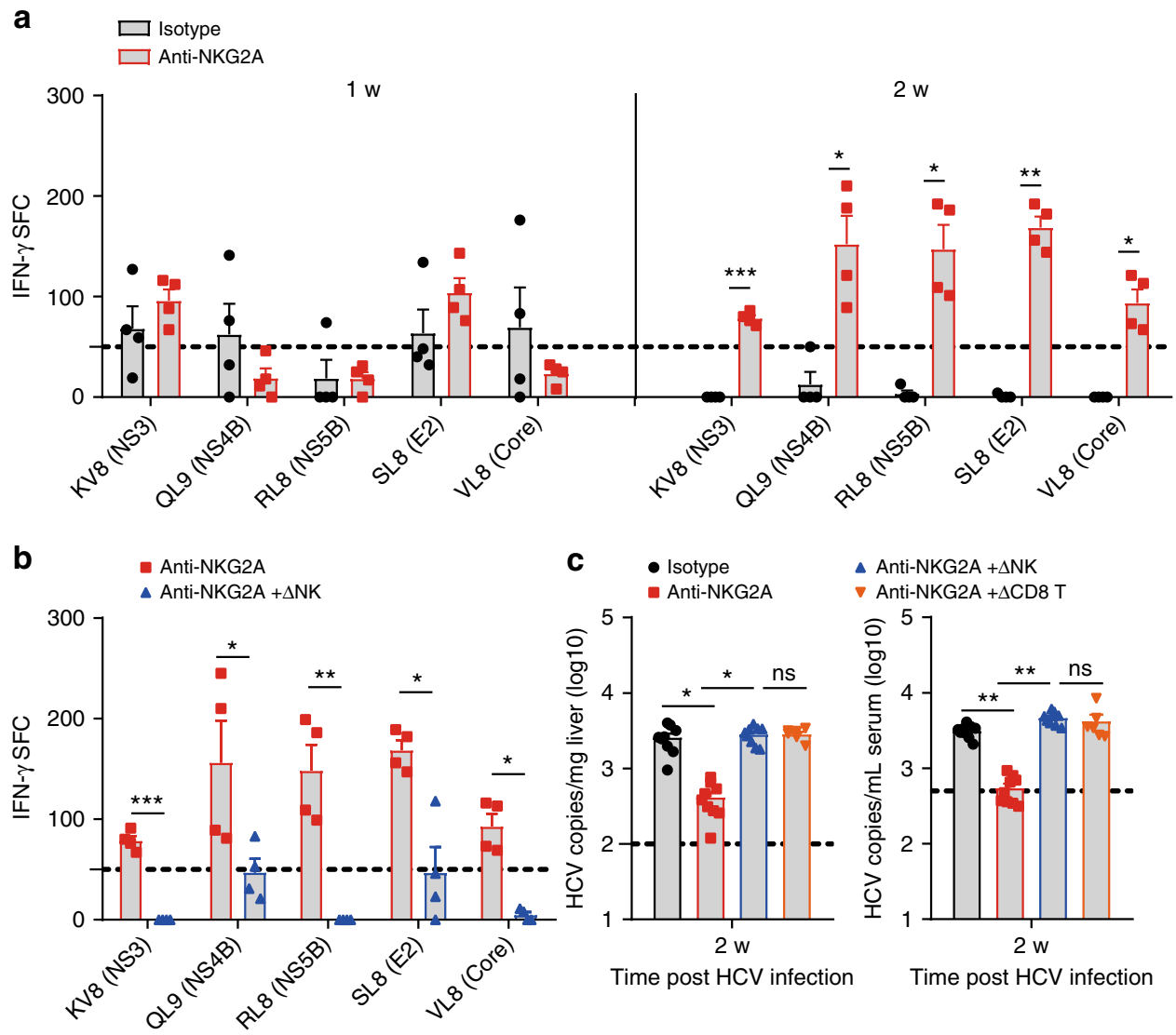

Fig. 4 NK cells instructed T cells in HCV persistence. a Mice were treated as in Fig. 3d. ELISpot assays using splenocytes and the indicated epitope peptides. C/OTg mice were i.p. pre-treated with mock $\operatorname{lgG}(n=9)$ or $\mathbf{b}$ anti-AGM1 $(20 \mu \mathrm{g} / 3$ days, $n=9)$, $\mathbf{c}$ anti-CD8 $(100 \mu \mathrm{g} / 3$ days, $n=6)$, together with anti-NKG2A antibody $1 \mathrm{~d}$ before HCV inoculation. $\mathbf{b} \mathrm{HCV}$-specific CD8 ${ }^{+} \mathrm{T}$ cell response by IFN- $\gamma$ ELISpot and $\mathbf{c}$ hepatic and serum HCV RNA copies were measured 2 wpi. Dash lines indicated limits of detection of related assays (qPCR, 500 copies $/ \mathrm{mL}$ serum or 100 copies $/ \mathrm{mg}$ liver; ELISpot, 50 spots $/ 4 \times 10^{5}$ splenocytes). Data were mean \pm SD, Student $t$-test. ${ }^{\star} P<0.05$; ${ }^{\star \star} P<0.01 ;{ }^{\star \star \star} P<0.001$. ns Not significant. Source data are provided as a Source Data file

Human HLA-E or mouse Qa-1 interacts with NKG2A to limit $\mathrm{NK}$ function. Indeed, HLA-E is upregulated in hepatocytes of $\mathrm{CHC}$ patients ${ }^{39}$. In line with this, mRNA level of Qa-1 was also rapidly increased in the liver of $\mathrm{HCV}$-infected $\mathrm{C} / \mathrm{O}^{\mathrm{Tg}}$ mice (Fig. 6a) or HCV-infected PHT (Supplementary Fig. 8C). Flow cytometry showed that Qa-1 upregulation was mainly restricted to hepatocytes but not intrahepatic immune cells (Fig. 6b). Furthermore, administration of a blocking antibody to Qa-1 (Fig. 6c) inhibited $\mathrm{HCV}$ replication in $\mathrm{C} / \mathrm{O}^{\mathrm{Tg}}$ mice (Fig. 6d), which simultaneously restored NK functions (Fig. 6e) and cytotoxic $\mathrm{CD}^{+} \mathrm{T}$ cell response, particularly to QL9 epitopes (Fig. 6f). To better characterize the role of Qa-1 in vivo, we delivered cholesterol conjugated siRNA by tail vein injection ${ }^{40}$ (Fig. 6g), which selectively downregulated Qa-1 in hepatocytes but not NPC (Supplementary Fig. 9). The partially reduced Qa-1 expression on hepatocytes sufficiently inhibited HCV replication (Fig. 6h), likely by activating NK cell function (Fig. 6i). Taken together, these results indicate that Qa-1/NKG2A interaction served as an innate immune checkpoint that impaired NK function, leading to subsequent $\mathrm{T}$ cell exhaustion, in establishment of HCV persistence.

Revived NK cells alleviate $\mathrm{CD8}^{+} \mathrm{T}$ cell exhaustion by IFN- $\gamma$. The aforementioned evidence suggests that the instructive role of NK cells on T cells, via cytolysis activity or cytokine secretion ${ }^{41}$, would have a role in the establishment of HCV persistence. To determine how NK cells regulated HCV-specific T cell response, we first tested whether the direct NK lysis of HCV-infected hepatocytes was involved in acute HCV infection, which is known to promote myeloid DC (mDC) maturation and antigen presenting capability, and therefore $\mathrm{T}$ cells activation ${ }^{42}$. However, liver infiltration (Supplementary Fig. 10A), maturation (CD40, CD80, CD86, and ICOSL, Supplementary Fig. 10B) or activation state (IL-12p40, Supplementary Fig. 10C) of mDC remained invariable, regardless of $\mathrm{NK}$ activities impaired or restored by anti-NKG2A treatment. Therefore, $\mathrm{mDC}$ cells would unlikely mediate NK-T signaling in HCV infection. Because anti-NKG2A revived IFN- $\gamma$ secreting capability of $\mathrm{NK}$ cells (Fig. 3g), we expected that $\mathrm{NK}$ might mediate activation of $\mathrm{T}$ cell response through IFN- $\gamma$. Intracellular staining indicated that the majority of IFN- $\gamma$ producing NPCs were NK, NKT, and T cells, but only NK cells showed a pronounced increase of IFN- $\gamma$ upon antiNKG2A treatment (Fig. 7a). On the other hand, antibody blockade of IFN- $\gamma$ completely ablated the capacity of antiNKG2A in revigorating HCV-specific T cell response (Fig. 7b) and reducing HCV replication (Fig. 7c). Therefore, these results suggest IFN- $\gamma$ secretion by NK cells would prevent the functional exhaustion of $\mathrm{HCV}$-specific $\mathrm{CD}^{+} \mathrm{T}$ cells, with $\mathrm{DC}$ cell dispensable. Because both activated $\mathrm{NK}$ and $\mathrm{CD}^{+} \mathrm{T}$ cells were required to clear $\mathrm{HCV}$ infection, the reduced $\mathrm{HCV}$ viral loads (Fig. 7c) would require IFN- $\gamma$ from both cells.

\section{Discussion}

Receiving both portal vein and arterial blood, the liver is an important and critical component in the defense against bloodborne infections. The liver acquires specialized mechanisms of 

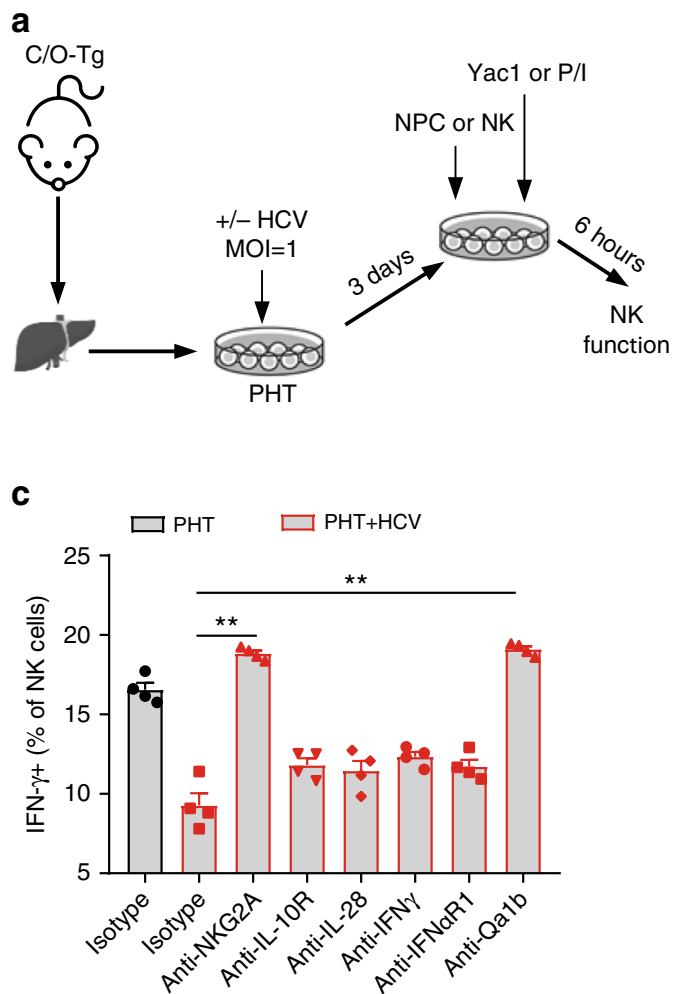

b

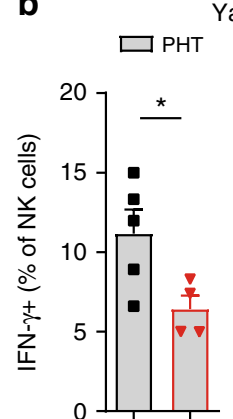

Yac-1 $\square \mathrm{PHT}+\mathrm{HCV}$

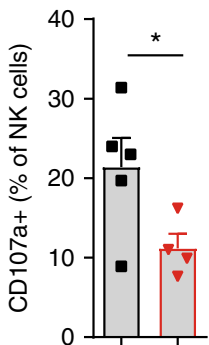

d

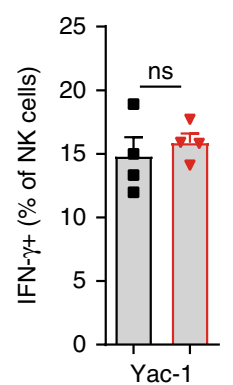

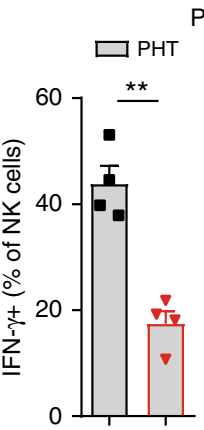

$\mathrm{P}+\mathrm{I}$

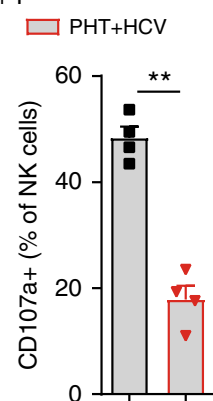

e
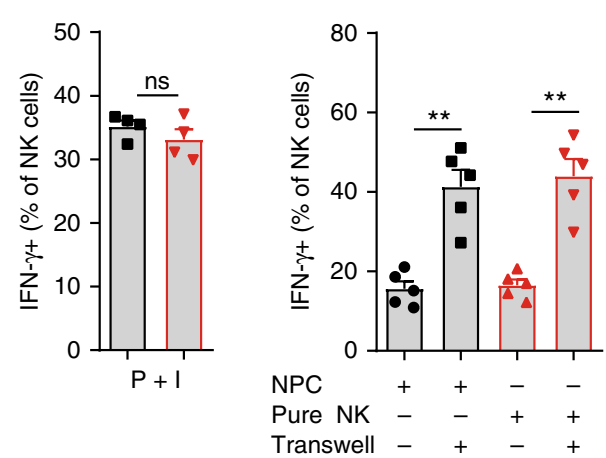

Fig. $5 \mathrm{HCV}$ infection of hepatocytes impaired hepatic NK cells function. a Flowchart of NK functional inhibition assays. PHTs $\left(2 \times 10^{5} / \mathrm{mL}\right)$ isolated from naive $\mathrm{C} / \mathrm{O}^{\top g}$ mice were infected with $\mathrm{HCVcc}(\mathrm{MOI}=1)$ for 3 days before NPCs $\left(1 \times 10^{6}\right)$ were added. Yac- 1 cells $\left(1 \times 10^{5} / \mathrm{well}\right)$ or PMA $(50 \mathrm{ng} / \mathrm{mL}) \mathrm{plus}$ ionomycin $(1 \mu \mathrm{M})$ were used to stimulate NK cells. b FACS analysis of intracellular IFN- $\gamma$ and CD107a of NK cells $6 \mathrm{~h}$ after stimulation. $\mathbf{c}$ Indicated blocking antibodies and isotype IgG were added to the PHT/NK co-culture assay. IFN- $\gamma$ expression of NK cells was detected $6 \mathrm{~h}$ after Yac-1 cell stimulation. d Measurement of intracellular IFN- $\gamma$ in NK cells after supernatants of PHTs after HCV infection (HCV-CM) were added to NPCs. Yac- 1 cells $\left(1 \times 10^{5} /\right.$ well) or PMA $(50 \mathrm{ng} / \mathrm{mL})$ plus ionomycin $(1 \mu \mathrm{M})$ were used to stimulate NK cells. e NPCs or MACS purified intrahepatic NK cells were co-cultured with or transwell separated from HCV-infected PHTs. IFN- $\gamma$ expression of NK cells was detected $6 \mathrm{~h}$ after Yac- 1 cell stimulation. Data were mean $\pm \mathrm{SD}$, Student t-test. ${ }^{\star} P<0.05 ;{ }^{\star \star} P<0.01$. ns Not significant. Source data are provided as a Source Data file

immune tolerance ${ }^{43}$, broadly by insufficient antigen presentation and a network of active immunosuppressive pathways mediated mostly by myeloid cells. Detailed mechanisms of how liver tropic viruses, such as $\mathrm{HBV}$ and $\mathrm{HCV}$, evade the immune surveillance to establish persistent infections remain vague ${ }^{44}$. Most studies rely on phenotypical or functional assays of PBMC or limited liver biopsies of $\mathrm{CHC}$ patients. Inadequate type I IFN, impaired DC presenting, impaired activation of $\mathrm{NK}$ and HCV-specific T cells have all been implicated to associate with $\mathrm{HCV}$ chronicity ${ }^{45}$. Only scarce clinical evidence suggests a correlation between peripheral NK activation and self-limited HCV infection ${ }^{13,14}$, but the dynamic function of intrahepatic NK cells has not been carefully studied. Furthermore, the ineffective virological response to IFN therapy suggests a more profound immune suppression needs to be overcome in $\mathrm{CHC}$ patients ${ }^{46}$.

Our study reveals that the sustained upregulation of NKG2A in intrahepatic $\mathrm{NK}$ cells had a major role in the induction and maintenance of NK cell exhaustion, which eventually leads to HCV persistence. Qa-1/NKG2A-mediated hepatocyte-NK cell interaction provided a insight of how $\mathrm{HCV}$ triggered tolerant milieu in the onset of $\mathrm{HCV}$ persistence. Plate-immobilized recombinant $\mathrm{HCV}$ E2 protein or $\mathrm{HCV}$ virus can inhibit cytokines-activated NK functions in vitro, but $\mathrm{HCV}$ in a live virion configuration is unlikely to suppress $\mathrm{NK}$ cells activity $^{32,34,47,48}$. Instead, this work showed, in support of previous notion ${ }^{49}$, that the physical interaction between NK cells and hepatocytes might account for NK cell exhaustion. HCV-infected hepatocytes can avoid $\mathrm{NK}$ recognition and cytotoxicity by upregulation of MHC I and release of specific inflammatory milieu $^{50}$. We identify in this work that NK cells were functionally exhausted by the increased NKG2A/Qa-1 interaction in a cell-cell contact fashion. Abrogation of either NKG2A or Qa-1 signaling, therefore, was sufficient to prevent NK cell exhaustion and inhibit HCV replication (Fig. 7d). Aberrant NKG2A/Qa-1 signaling for NK cell exhaustion is also implicated in other chronic viral infections, where $\mathrm{MCMV}^{51}$ or $\mathrm{HSV}-1^{52}$ may escape immune surveillance through upregulation of Qa-1. Elevated HLA-E/ NKG2A-mediated inhibition impairs NK cell clearance of HIVinfected target cells ${ }^{53}$. Of relevance, Treg cell-derived IL-10 can elevate NKG2A in NK cells in a mouse model of chronic HBV infection, and NKG2A blockade limits HBV replication ${ }^{38}$. Taken together, NKG2A may serve as an important innate immune checkpoint in establishment of chronic viral infections.

Both NK and T cells express NKG2A, and recent studies indicate that NKG2A checkpoint inhibition also promotes antitumor function of both NK and T cells ${ }^{54,55}$. We establish that NK cell activation precedes $\mathrm{T}$ cell response to $\mathrm{HCV}$, and reversal of NK cell exhaustion helped reactivating HCV multi-specific CD8 ${ }^{+}$ $\mathrm{T}$ cell response. Therefore, NK cell exhaustion would predominate the tolerant milieu in $\mathrm{HCV}$ persistent infection. NKG2A in intrahepatic NK cells, but not T cells, would account for the establishment of $\mathrm{HCV}$ persistent infection. This role of intrahepatic NK cells may be unique to $\mathrm{HCV}$, because other studies show that activated NK cells can directly lyse LCMVspecific $\mathrm{CD}^{+} \mathrm{T}$ cells, leading to $\mathrm{CD}^{+} \mathrm{T}$ cell exhaustion and LCMV persistence ${ }^{56,57}$. Moreover, nucleos(t)ide analog (NUC) 


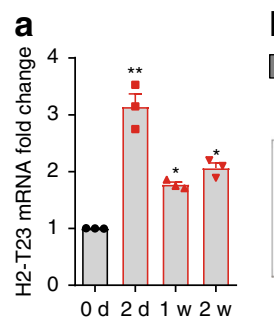

b
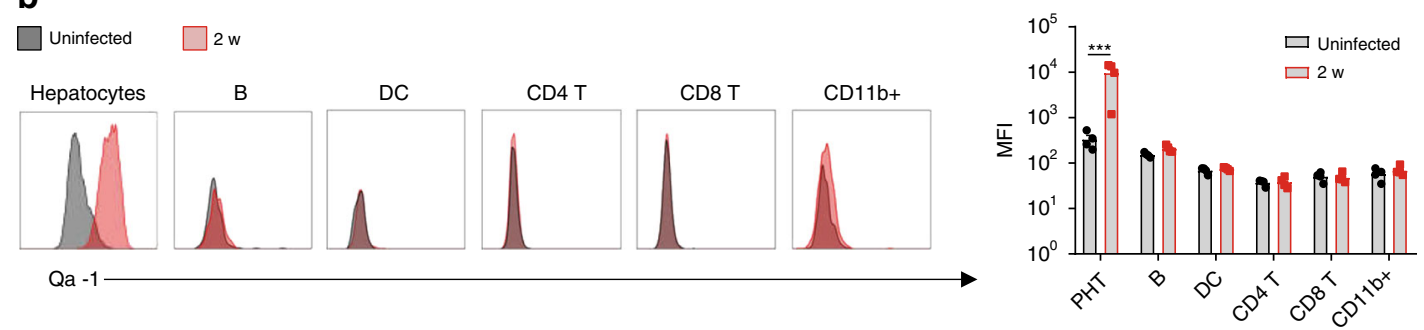

C

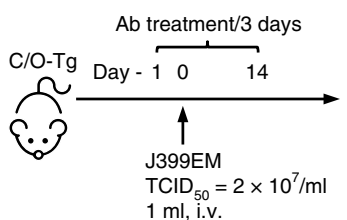

g

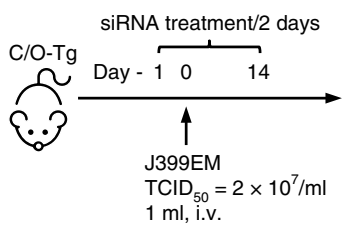

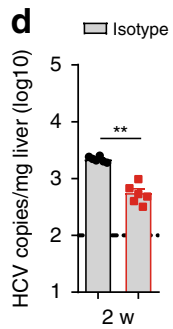
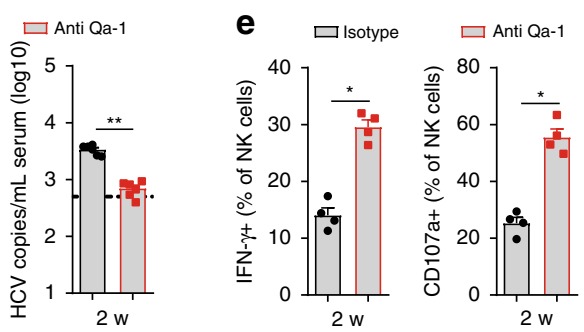

f

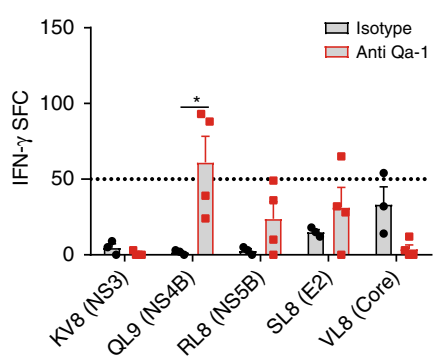

i

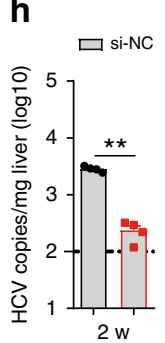

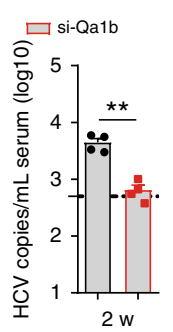

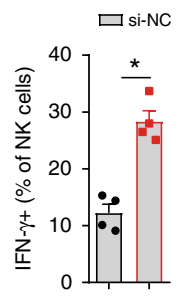

Yac-1

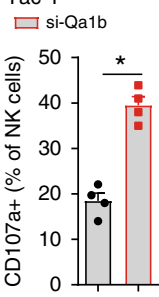

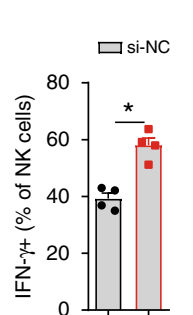

$P+I$

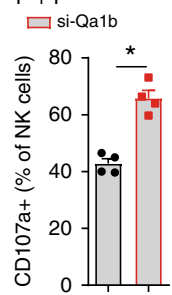

Fig. 6 Upregulation of Qa-1 on hepatocytes accounted for NK cell dysfunction upon HCV infection. a Measurement of Qa-1 mRNA in liver isolated from C/ $\mathrm{O}^{\mathrm{Tg}}$ mice $(n=3)$ at the indicated time post HCV infection. b FACS analysis of Qa-1 expression on hepatocytes or NPC subsets as indicated before or 2 weeks post HCV infection. $\mathbf{c}$ C/OTg mice ( $n=6$ each group) were i.p with Qa- 1 blocking antibody or isotype lgG (100 $\mu \mathrm{g} / 3$ days). d HCV RNA copies in serum and liver, e CD107a and IFN- $\gamma$ expression in hepatic NK cells upon Yac-1 cell stimulation, $\mathbf{f} \mid \mathrm{FN}-\gamma$ ELISpot assays of T cells stimulated by the indicated epitopes, were assayed 2 wpi. $\mathbf{g} \mathrm{C} / \mathrm{O}^{\top \mathrm{Tg}}$ mice ( $n=4$ each group) were i.v. injected with liposomes/siRNA complex at a dose of $2.5 \mathrm{mg} / \mathrm{kg}$ every 3 days since day -1 . Mice were killed at 2 wpi. $\mathbf{h}$ HCV RNA copies in serum and liver, $\mathbf{i}$ CD107a and IFN- $\gamma$ expression in hepatic NK cells upon Yac-1 cell or $\mathrm{P}+\mathrm{I}$ stimulation as indicated. Dash lines indicated limits of detection of related assays. Data were mean $\pm \mathrm{SD}$, Student $t$-test. ${ }^{\star} P<0.05$; ${ }^{* \star} P<0.01$; ${ }^{\star \star \star} P<0.001$. ns Not significant. Source data are provided as a Source Data file

therapy restores $\mathrm{HBV}$-specific $\mathrm{T}$ cells function ${ }^{58}$ with concomitant inactivation of NK functions ${ }^{59}$. NK depletion, as well as TRAIL and NKG2D blockade, can significantly enhance HBVspecific T-cell functions ${ }^{59}$. Further, NK lytic activity on T cells may be counteracted by $\mathrm{Qa}-1$ in $\mathrm{CD} 4^{+} \mathrm{T}$ cells signaling to NKG2 $\mathrm{A}^{60}$. Therefore, the action of Qa-1/NKG2A in chronic $\mathrm{HCV}$ infection of $\mathrm{C} / \mathrm{O}^{\mathrm{Tg}}$ mice revealed a different mechanism, whereas NKG2A blockade helped to prevent NK cell exhaustion and reverse $\mathrm{CD}^{+} \mathrm{T}$ cell exhaustion, likely through increased secretion of IFN- $\gamma$ by NK cells. Such a "one stone and two birds" effect of NK checkpoint therapy was recently suggested in TIGIT blockage therapy, which simultaneously prevents NK cell exhaustion and restores $\mathrm{CD}^{+} \mathrm{T}$ cell-mediated anti-tumor immunity $^{61}$, albeit NK-T interaction mechanism has not been described. Therefore, the unique nature of NK cell activation and exhaustion, and the distinct cytokine milieu may determine different outcomes of NK-T interaction in different sets of persistent infections ${ }^{41}$.

In sum, we were able to take full advantage of the immunecompetent mouse model of HCV natural infection, to decipher the dynamic NK-T cell interactions within the liver along the course of infection. Qa-1/NKG2A interaction linked the pathogen to host immunity, and accounted for impaired NK/T functions in the establishment of $\mathrm{HCV}$ persistence. Direct-acting antiviral medications (DAA) are becoming a promising cure of hepatitis C. However, emerging data indicate that individuals who have been cured with DAAs remain susceptible to reinfection ${ }^{62,63}$. This may be largely caused by a limited restoration of the protective immunity, as indicated in a study with chimpanzee model of HCV infection ${ }^{64}$. NKG2A checkpoint inhibitor treatment can boost both innate and adaptive immune responses. Considering that NKG2A antibody (monalizumab) has already been in numerous clinical trials on treatment of rheumatoid arthritis, cancer and stem-cell transplantation ${ }^{65}$, a combined NKG2A checkpoint treatment and DAA therapy would avoid the risk of late relapse or reinfection after achieving a sustained virological response via DAA therapies.

\section{Methods}

Virus stocks. HCVcc stocks were prepared from a J399EM infectious clone ${ }^{66}$ and virus titers $\left(\mathrm{TCID}_{50}\right)$ in supernatants and cell lysates were measured by endpoint dilution assays (EPDA) ${ }^{67}$. Sera positive for HCV1b were obtained from CHC patients before IFN/ribavirin therapy. Individuals with a history of $\mathrm{HBV}, \mathrm{HEV}$, HDV, HIV, recent infectious diseases, or other inflammatory diseases (such as rheumatoid arthritis, diabetes, autoimmune hepatitis, hypertension, kidney disease) were excluded. Written informed consent was obtained from all patients, and the experimental protocol was approved by the Ethics Committee of the First Hospital of Jilin University, China (approval code: 130801-067). 
a

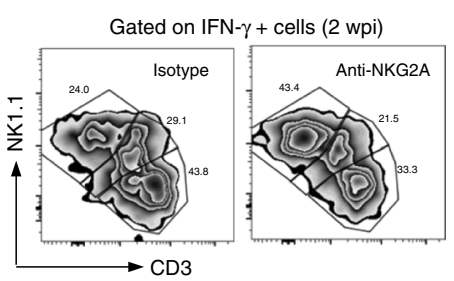

b

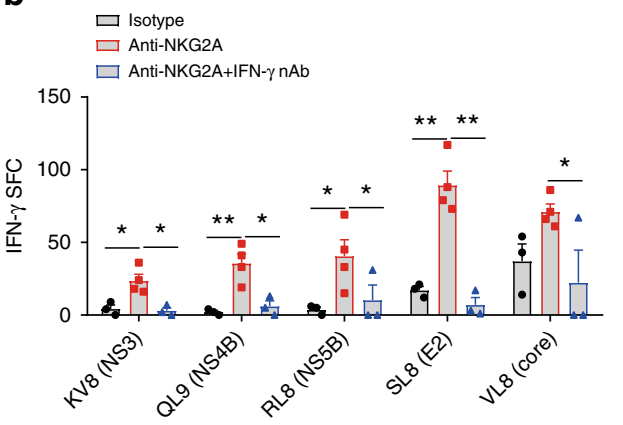

口Isotype

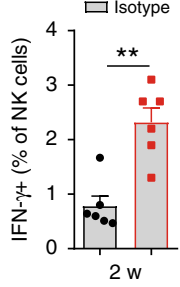

C $\square$ Isotype

$\square$ Anti-NKG2A

$\square$ Anti-NKG2A +

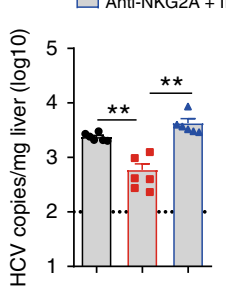

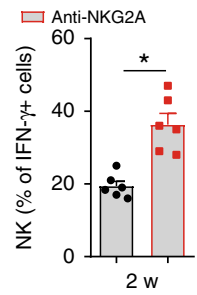

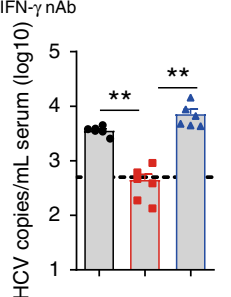

d

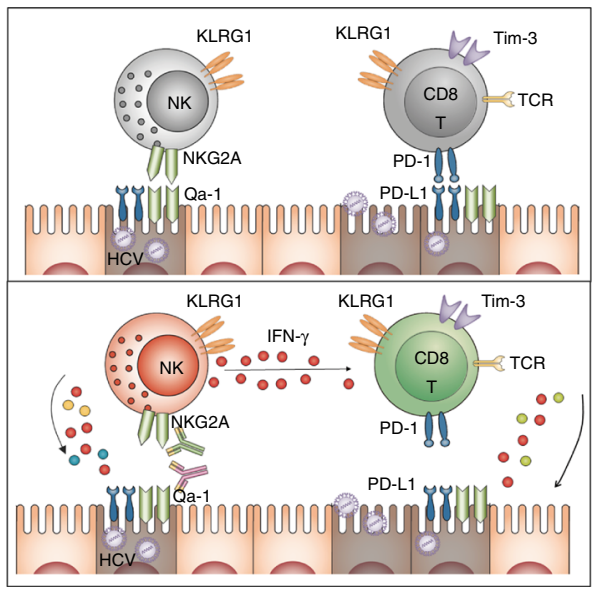

Fig. 7 Anti-NKG2A restored T cell response through enhanced IFN- $\gamma$ production. a FACS analysis of hepatic IFN- $\gamma$ positive cells with or without NKG2A blockade 2 wpi. b, c C/O ${ }^{T g}$ mice ( $n=6$ each group) were i.p. pre-treated with IFN- $\gamma$ neutralization antibody or isotype lgG (100 $\mu \mathrm{g} / 3$ days) together with anti-NKG2A antibody $1 \mathrm{~d}$ before HCV inoculation. $\mathbf{b} \mathrm{HCV}$-specific CD8 ${ }^{+} \mathrm{T}$ cell response by IFN- $\gamma$ ELISpot and $\mathbf{c}$ serum and hepatic HCV RNA copies were measured 2 wpi. d Diagram of Qa-1/NKG2A immune checkpoint during HCV infection. Dash lines indicated limits of detection of related assays. Data were mean \pm SD, Student $t$-test. ${ }^{\star} P<0.05 ;{ }^{\star} P<0.01$. Source data are provided as a Source Data file

Mice. Immune-competent $\mathrm{C} / \mathrm{O}^{\mathrm{Tg}}$ mice that support $\mathrm{HCV}$ persistent infection with appropriate hepatopathogenesis were used in this study ${ }^{19}$. For in vivo experiments, 8- to 12 -week old, age- and gender-matched $\mathrm{C} / \mathrm{O}^{\mathrm{Tg}}$ and wt littermates were used. Wt mice were littermates by crossing founder $\mathrm{C}^{\mathrm{Tg}}$ and $\mathrm{O}^{\mathrm{Tg}}$ mice ${ }^{19}$. All mice were maintained under specific pathogen-free conditions and treated in accordance to protocols approved by the Institute of Biophysics, Chinese Academy of Sciences Institutional Laboratory Animal Care and Use Committee. Infection experiments were conducted in a BSL2-enhanced Animal Care facility. Hereby mice were tail vein perfused with HCV J399EM or HCV patient sera (Genotype 1b) as described previously ${ }^{19,21}$. There was no blinding in infection experiments. Genders of mice used in different assays were random. For experiments that $\mathrm{HCV}$-specific $\mathrm{CD}{ }^{+} \mathrm{T}$ cell were examined by ELISpot, $\mathrm{C} / \mathrm{O}^{\mathrm{Tg}}$ mice positive for similar levels of $\mathrm{H}-2$ class I histocompatibility antigens $\left(\mathrm{H}-2-\mathrm{K}^{\mathrm{b}}, \mathrm{H}-2-\mathrm{K}^{\mathrm{d}}, \mathrm{H}-2-\mathrm{K}^{\mathrm{k}}\right)$ and NKG2A were used.

Cell depletion and inhibition of surface proteins in vivo. $\mathrm{C} / \mathrm{O}^{\mathrm{Tg}}$ mice were i.p. treated with anti-NKG2A/C/E (100 $\mu$ g, q.3d. clone 20d5; eBioscience) or anti-Qa-1 (100 $\mu$ g, q.3d. 6A8.6F10.1A6; BD Pharmingen) to block the NKG2A-Qa-1 interaction. Where indicated, NK depletion antibody $(20 \mu \mathrm{g}$, q.3d. clone Poly21460, BioLegend), $\mathrm{CD}^{+} \mathrm{T}$ depletion antibody (100 $\mu \mathrm{g}$, q.3d. clone TIB210) or anti-IFN$\gamma$ antibody (100 $\mu$ g, q.3d. clone R4-6A2, eBioscience) was i.p. injected 1 day before $\mathrm{C} / \mathrm{O}^{\mathrm{Tg}}$ mice or wt littermates were infected with HCV. PD-1 antibody $(200 \mu \mathrm{g}$, q.3d. clone G4, kindly provided by Prof. S. Wang, Institute of Biophysics, CAS) and Tim-3 antibody (100 $\mu$ g, q.2d. clone BE0115, BioXcell) were i.p. administrated alone or in combination as indicated 1 day before HCV inoculation, for 2 weeks or 1 month. For siRNA knockdown in vivo, on three consecutive days, Qa-1 or negative control $(\mathrm{NC})$ cholesterol conjugated siRNA were packaged using the Lipofectamine 2000 (Invitrogen), tail vein injected at a dose of $2.5 \mathrm{mg} / \mathrm{kg}$ in $\sim 0.3$ $\mathrm{mL}$ PBS. The sense siRNA strand used for Qa-1 was: GAAGAGGAGGAGACACAUA. SiRNAs were synthesized by GenePharma (Shanghai, China). Primers for Qa-1 mRNA were: H2-T23-F: CCTCCATCCACTGTCTCCAA, H2-T23-R: ACCTA TGTGTCTCCTCCTCTTC; GAPDH mRNA: Gapdh-F: ACGGCCGC ATCTT CTTGTGCA, Gapdh-R: ACGGCCAAATCCGTTCACACC.

Murine hepatic non-parenchymal cell preparation. NPCs were isolated as previously described with minor modifications ${ }^{68}$. In brief, liver tissues were passed through a 200-gauge stainless steel mesh in Hank's balanced salt solution (GIBCO). The cell suspension was centrifuged at $500 \mathrm{~g}$ for $5 \mathrm{~min}$, and the resulting cell pellets were re-suspended in $5 \mathrm{~mL} 35 \%$ Percoll (GE Life Science), centrifuged at $500 \times g$ for $10 \mathrm{~min}$ at room temperature. The cell pellets containing leukocytes were resuspended in $1 \mathrm{~mL}$ red blood cell lysis solution (BD) on ice for $2 \mathrm{~min}$. After washed twice in RPMI 1640 containing 5\% FBS, the yielded NPCs were tested for viability (more than $95 \%$ ) by trypan blue exclusion.
Peptides and IFN- $\boldsymbol{\gamma}$ ELISpot assay. The MHC class I restricted $\left(\mathrm{H}-2-\mathrm{K}^{\mathrm{b}}, \mathrm{H}-2-\mathrm{K}^{\mathrm{d}}\right.$, and $\left.\mathrm{H}-2-\mathrm{K}^{\mathrm{k}}\right)$ peptides from HCV Core, E2, NS3, NS4, NS5A, and NS5B antigens (8-11 amino acids, overlapping peptides) were predicted using IEDB (http://www. iedb.org). Based on the calculated binding affinity to MHC, epitopes were selected for ELISpot assays $\left(\mathrm{IC}_{50}<50 \mathrm{nM}\right.$, Supplementary Table 1). Where patient sera positive for HCV1b were used for infection, an array of 376 overlapping peptides (individual length of 18 amino acids, with 10 amino acids overlaps), covering the entire HCV polyprotein was used ${ }^{69}$. In the ELISpot assay 20-30 peptides were pooled to cover NS3, NS4B, NS5A, and NS5B, respectively. (for pool information see Supplementary Table 2). All peptides were synthesized (GL Biochem, Shanghai) and reconstituted in DMSO as stocks.

Anti-IFN- $\gamma$ Enzyme-linked ImmunoSpot (ELISpot) assays were performed according exactly to manufacturer's protocol (BD). Specifically, splenocytes $(4 \times$ $10^{5}$ in RPMI supplemented with $10 \% \mathrm{FBS}, 50 \mathrm{U} / \mathrm{mL}$ penicillin/streptomycin, $50 \mathrm{mM} \beta$-mercaptoethanol) were seeded on IFN- $\gamma$ antibody coated 96-well PVDF membrane plates (IFN- $\gamma$ ELISpot Set, BD). Individual HCV peptide (final concentration $4 \mu \mathrm{g} / \mathrm{mL}$ ) was then added to corresponding wells. PHA and OVA peptides were used as positive or negative control, respectively. After incubation for $2.5 \mathrm{~d}$, the IFN- $\gamma$ secreting spots were developed and were counted in a blind fashion outsourced to Dakewe (Shenzhen, China), using an automated ELISpot reader system (Cellular Technology). Data were analyzed with software Immunospot 5.0.32. Sensitivity $>50$ spots $/ 4 \times 10^{5}$ cells was considered as positive in IFN- $\gamma$ production and IFN- $\gamma$ secreting spots of OVA peptides were subtracted as background.

Primary hepatocytes infection. PHT were isolated from $\mathrm{C} / \mathrm{O}^{\mathrm{Tg}}$ mice by a two-step collagenase perfusion protocol. In brief, the hepatic portal vein was ligated and perfused first with HBSS containing $5 \mathrm{mM}$ EDTA without $\mathrm{Ca}_{2}{ }^{+}$and $\mathrm{Mg}^{+}$(Beyotime Co., China), then with HBSS containing $0.025 \%$ type IV collagenase (Sigma-Aldrich). After perfusion, the liver was excised and hepatocytes were suspended in serum-free DMEM (Gibco, MD, USA) and passed through a $100-\mu \mathrm{m}$ strainer. The filtrate was centrifuged $\left(50 \times g\right.$ at $4{ }^{\circ} \mathrm{C}$ for $3 \mathrm{~min}$ ), and the pelleted hepatocytes were re-suspended in WEM containing $10 \%$ FBS (Gibco, MD, USA). PHTs were seeded $\left(2 \times 10^{5} / \mathrm{mL}\right)$ in 24 well plates and rested overnight, then infected with HCV J399EM $(\mathrm{MOI}=1)$ as described previously ${ }^{19}$. Three days later, fresh isolated NPCs or purified NK cells were added and co-culture for $6 \mathrm{~h}$. NK cell function was evaluated by Yac-1 cell or PMA/ ionomycin stimulation assay. To obtain HCV-conditioned medium, the supernatants were collected $72 \mathrm{~h}$ post $\mathrm{HCV}$ infection.

Flow cytometry. Hepatic NPCs were isolated at indicated time post HCV infection as previously described ${ }^{19}$. Cells suspended in PBS containing 2\% FBS (Gibco) were counted using Beckman Z2 counter (Beckman). For surface staining, cells were incubated with Fc blocker (1:100, clone 93, Biolegend) and indicated antibodies in FACS buffer at $4^{\circ} \mathrm{C}$ for $40 \mathrm{~min}$. To measure intracellular proteins, cells were first 
stained with the indicated surface antibodies, then fixed and permeabilized in cytofix/cytoperm (eBioscience) on ice for $30 \mathrm{~min}$. After washed with perm/wash buffer (eBioscience), cells were incubated with antibodies towards indicated intracellular antigens at $4{ }^{\circ} \mathrm{C}$ for $1 \mathrm{~h}$. Multi-color flow cytometry was performed on LSRFortessa (BD Biosciences, NJ). The following antibodies were from BioLegend and used according to the manufacturer's instructions: FITC-CD4 (GK1.5, 1:400), FITC-NK1.1 (PK136, 1:400), BV605-CD8a (53-6.7, 1:400), PECy7-CD3E (1452C11, 1:400), PECy7-F4/80 (BM8, 1:400), APCCy7-CD11b (M1/70, 1:400), PerCPCy5.5-DX5 (HMa2, 1:400), PECy7-KLRG1 (2F1/KLRG, 1:200), PECy7-CD27 (LG.3A10, 1:400), APCCy7-CD107a (1D4B, 1:200), Bv421-NKp46 (29A1.4, 1:400), APC-Ly49D (415, 1:400), Bv605-CD69 (HE1.2F3, 1:200), APC-Granzyme B (GB11, 1:200), PB-Ly49H (3D10, 1:400), PB-Ly49A (YE1/48.10.6, 1:400), PECy7-Ly49C/F/ I/H (14B11, 1:400), APCCy7-Ly49G (AT8, 1:400), PE-Tim3 (B8.2C12, 1:200), APCPD-1 (29F.1A12, 1:200), PECy7-TIGIT (1G9, 1:200). The following antibodies were from eBioscience and used according to the manufacturer's instructions: APCNKG2D (CX5, 1:200), Biotin-NKG2A (20D5, 1:200), Biotin-Qa1 (6A8.6F10.1A6, 1:200), PE-IFN- $\gamma$ (XMG1.2, 1:200). For intrahepatic IFN- $\gamma$ expression, NPCs $(1 \times$ $10^{6}$ ) isolated from $\mathrm{C} / \mathrm{O}^{\mathrm{Tg}}$ liver, were incubated with $50 \mathrm{ng} / \mathrm{mL}$ PMA and $1 \mu \mathrm{g} / \mathrm{mL}$ ionomycin in $200 \mu \mathrm{L}$ RPMI complete medium for $6 \mathrm{~h}$. BFA (eBioscience) was added $(1: 1000) 1 \mathrm{~h}$ post co-culture. Surface and intracellular protein expressions were examined by FACS after staining. Data of at least three independent experiments were analyzed with FlowJo Software (Tree Star, version 7.6, OR).

NK cell-mediated cytotoxicity assay. NPCs $\left(1 \times 10^{6}\right)$ or MACS purified NK cells $\left(2 \times 10^{5}\right)$ were mixed with Yac-1 cells $\left(1 \times 10^{5}\right)$ or stimulated with 50 ng PMA and 1 $\mu \mathrm{M}$ ionomycin in $200 \mu \mathrm{L}$ RPMI medium for $6 \mathrm{~h}$. BFA (eBioscience) was added $(1: 1000) 1 \mathrm{~h}$ post co-culture to block cytokine secretion and meanwhile, BV421conjugated anti-CD107a antibody was added at the beginning of incubation to detect lysosome synthesis. After stimulation, cells were harvested for detection of intracellular IFN- $\gamma$. First, the cells were stained for NKp46 and CD3, and then fixed/ permeabilized with BD Cytofix/Cytoperm Buffer (BD Biosciences). These cells were then stained with anti-IFN- $\gamma$-PE. Data were collected on LSRFortessa (BD Biosciences, NJ) and analyzed with FlowJo Software (Tree Star, version 7.6, OR).

Cytokine measurement. Indicated cytokines and chemokines in serum were analyzed by Procartaplex Mouse 24-plex kit (eBioscience). In brief, sera $(10 \mu \mathrm{L})$ from $\mathrm{HCV}$-infected wt or $\mathrm{C} / \mathrm{O}^{\mathrm{Tg}}$ mice were first incubated with 24 -plex beads $(25 \mu \mathrm{L}), 10 \mu \mathrm{L}$ detection antibody and $20 \mu \mathrm{L}$ streptavidin-PE were then added sequentially with interval washes. Samples prepared in $120 \mu \mathrm{L}$ sheath fluid were analyzed on a FLEXMAP 3D system with xPONENT software (Luminex).

Statistical analysis. Power: In compliance with ethical guidelines to minimize the number of animals used, we usually used a minimum of three mice for each data point (except indicated in figure legend) to ensure statistical power. The sample size is thus determined according to the duration of experiments and number of data points pre-determined. Batches of infection were carried out to ensure accuracy, repeatability and enough animals for each data point.

Randomization: Measures had been taken to ensure randomization. Mice are grouped with the matched age, gender, body weight, and timing of experiments, between two cohorts. To form the cohort, each batch of infection, for example, contained the number of mice more than the number of data points, to ensure the randomization and accidental exclusion of animals. The cohort was then grouped using randomly selected animals from the batches of infection. In vitro analyses (HCV copies, cytokines, and chemokines) were usually performed on specimen (sera, liver) from animals at each time point to ensure a minimal three biological replicates.

Statistics: Routinely, data collection and data analysis were performed by different persons, to blind the potential bias. All measurements data are expressed as mean \pm SD to show maximal derivations, unless otherwise specified. Differences between two groups were assessed using unpaired two-tailed Student $t$-test. For multi-time-points data, the two-way ANOVA procedure was applied. Statistical tests are justified as appropriate. Data were in normal distribution, after variation within each group of data were estimated. The variance usually was within the range of statistic similarity. $P$-values $<0.05$ were considered significant. Statistical analyses were performed using GraphPad Prism.

Reporting Summary. Further information on experimental design is available in the Nature Research Reporting Summary linked to this article.

\section{Data availability}

The authors declare that the data supporting the findings of this study are available within the paper and its Supplementary Information files, or from the authors on reasonable request. Primary data for the graphs and statistical analyses are found in the Source Data file.

Received: 9 August 2018 Accepted: 18 February 2019

Published online: 03 April 2019

\section{References}

1. Messina, J. P. et al. Global distribution and prevalence of hepatitis C virus genotypes. Hepatology 61, 77-87 (2015).

2. Vescovo, T., Refolo, G., Vitagliano, G., Fimia, G. M. \& Piacentini, M. Molecular mechanisms of Hepatitis $\mathrm{C}$ virus-induced hepatocellular carcinoma. Clin. Microbiol. Infect. 22, 853-861 (2016).

3. Bengsch, B. et al. Coexpression of PD-1, 2B4, CD160 and KLRG1 on exhausted HCV-specific CD8 $+\mathrm{T}$ cells is linked to antigen recognition and $\mathrm{T}$ cell differentiation. PLoS Pathog. 6, e1000947 (2010).

4. Fuller, M. J. et al. Immunotherapy of chronic hepatitis $\mathrm{C}$ virus infection with antibodies against programmed cell death-1 (PD-1). Proc. Natl Acad. Sci. USA 110, 15001-15006 (2013).

5. Gardiner, D. et al. A randomized, double-blind, placebo-controlled assessment of BMS-936558, a fully human monoclonal antibody to programmed death-1 (PD-1), in patients with chronic hepatitis C virus infection. PLoS ONE 8, e63818 (2013)

6. Nakamoto, N. et al. Synergistic reversal of intrahepatic HCV-specific CD8 T cell exhaustion by combined PD-1/CTLA-4 blockade. PLoS Pathog. 5, e1000313 (2009).

7. Fisicaro, P. et al. Combined blockade of programmed death-1 and activation of CD137 increase responses of human liver T cells against HBV, but not HCV. Gastroenterology 143, 1576-1585.e1574 (2012).

8. Vivier, E., Tomasello, E., Baratin, M., Walzer, T. \& Ugolini, S. Functions of natural killer cells. Nat. Immunol. 9, 503 (2008).

9. Peng, H., Wisse, E. \& Tian, Z. Liver natural killer cells: subsets and roles in liver immunity. Cell. Mol. Immunol. 13, 328-336 (2016).

10. Long, E. O., Sik Kim, H., Liu, D., Peterson, M. E. \& Rajagopalan, S. Controlling natural killer cell responses: integration of signals for activation and inhibition. Annu. Rev. Immunol. 31, 227-258 (2013).

11. Rehermann, B. Pathogenesis of chronic viral hepatitis: differential roles of T cells and NK cells. Nat. Med. 19, 859-868 (2013).

12. Amadei, B. et al. Activation of natural killer cells during acute infection with hepatitis C virus. Gastroenterology 138, 1536-1545 (2010).

13. Werner, J. M. et al. Innate immune responses in hepatitis $C$ virus-exposed healthcare workers who do not develop acute infection. Hepatology 58, 1621-1631 (2013).

14. Pelletier, S. et al. Increased degranulation of natural killer cells during acute $\mathrm{HCV}$ correlates with the magnitude of virus-specific T cell responses. J. Hepatol. 53, 805-816 (2010).

15. Jinushi, M. et al. Negative regulation of NK cell activities by inhibitory receptor CD94/NKG2A leads to altered NK cell-induced modulation of dendritic cell functions in chronic hepatitis $\mathrm{C}$ virus infection. J. Immunol. 173, 6072-6081 (2004)

16. Kawarabayashi, N. et al. Decrease of CD56(+)T cells and natural killer cells in cirrhotic livers with hepatitis $\mathrm{C}$ may be involved in their susceptibility to hepatocellular carcinoma. Hepatology 32, 962-969 (2000).

17. Varchetta, S. et al. Impaired intrahepatic natural killer cell cytotoxic function in chronic hepatitis C virus infection. Hepatology 56, 841-849 (2012).

18. Khakoo, S. I. et al. HLA and NK cell inhibitory receptor genes in resolving hepatitis C virus infection. Science 305, 872-874 (2004).

19. Chen, J. et al. Persistent hepatitis $C$ virus infections and hepatopathological manifestations in immune-competent humanized mice. Cell Res. 24 1050-1066 (2014)

20. Chen, J. et al. The metabolic regulator histone deacetylase 9 contributes to glucose homeostasis abnormality induced by hepatitis $\mathrm{C}$ virus infection. Diabetes 64, 4088-4098 (2015).

21. Wang, Z. et al. Quinolinate phosphoribosyltransferase is an antiviral host factor against hepatitis C virus infection. Sci. Rep. 7, 5876 (2017).

22. Chen, J. et al. The RNA-binding protein ROD1/PTBP3 cotranscriptionally defines AID-loading sites to mediate antibody class switch in mammalian genomes. Cell Res. 28, 981-995 (2018).

23. Cao, L. et al. Identification of serotonin $2 \mathrm{~A}$ receptor as a novel HCV entry factor by a chemical biology strategy. Protein Cell 10, 178-195 (2018).

24. Bowen, D. G. \& Walker, C. M. Adaptive immune responses in acute and chronic hepatitis C virus infection. Nature 436, 946 (2005).

25. Fahey, S., Dempsey, E. \& Long, A. The role of chemokines in acute and chronic hepatitis C infection. Cell. Mol. Immunol. 11, 25 (2014).

26. Larrubia, J.-R., Moreno-Cubero, E., Miquel, J. \& Sanz-de-Villalobos, E. Hepatitis $C$ virus-specific cytotoxic $T$ cell response restoration after treatmentinduced hepatitis C virus control. World J. Gastroenterol. 21, 3480 (2015).

27. Zehn, D., Utzschneider, D. T. \& Thimme, R. Immune-surveillance through exhausted effector T-cells. Curr. Opin. Virol. 16, 49-54 (2016).

28. Mühlbauer, M. et al. PD-L1 is induced in hepatocytes by viral infection and by interferon-alpha and -gamma and mediates T cell apoptosis. J. Hepatol. 45, 520-528 (2006).

29. McMahan, R. H. et al. Tim-3 expression on PD-1+ HCV-specific human CTLs is associated with viral persistence, and its blockade restores hepatocytedirected in vitro cytotoxicity. J. Clin. Invest. 120, 4546 (2010). 
30. Borrego, F., Masilamani, M., Marusina, A. I., Tang, X. \& Coligan, J. E. The CD94/NKG2 family of receptors. Immunol. Res. 35, 263-277 (2006).

31. Shoukry, N. H., Pelletier, S. \& Chang, K. M. A view to natural killer cells in hepatitis C. Gastroenterology 141, 1144 (2011).

32. Yoon, J. C., Shiina, M., Ahlenstiel, G. \& Rehermann, B. Natural killer cell function is intact after direct exposure to infectious hepatitis $\mathrm{C}$ virions. Hepatology 49, 12-21 (2009).

33. Oliviero, B. et al. Hepatitis C virus-induced NK cell activation causes metzincin-mediated CD16 cleavage and impaired antibody-dependent cytotoxicity. J. Hepatol. 66, 1130-1137 (2017).

34. Crotta, S., Brazzoli, M., Piccioli, D., Valiante, N. M. \& Wack, A. Hepatitis C virions subvert natural killer cell activation to generate a cytokine environment permissive for infection. J. Hepatol. 52, 183-190 (2010).

35. Holder, K. A., Stapleton, S. N., Gallant, M. E., Russell, R. S. \& Grant, M. D. Hepatitis C virus-infected cells downregulate NKp30 and inhibit ex vivo NK cell functions. J. Immunol. 191, 3308-3318 (2013).

36. Wilson, E. B. et al. Blockade of chronic type I interferon signaling to control persistent LCMV infection. Science 340, 202-207 (2013).

37. Teijaro, J. R. et al. Persistent LCMV infection is controlled by blockade of type I interferon signaling. Science 340, 207-211 (2013).

38. Li, F. et al. Blocking the natural killer cell inhibitory receptor NKG2A increases activity of human natural killer cells and clears hepatitis B virus infection in mice. Gastroenterology 144, 392-401 (2013).

39. Nattermann, J. et al. The HLA-A2 restricted T cell epitope HCV core 35-44 stabilizes HLA-E expression and inhibits cytolysis mediated by natural killer cells. Am. J. Pathol. 166, 443-453 (2005).

40. Soutschek, J. et al. Therapeutic silencing of an endogenous gene by systemic administration of modified siRNAs. Nature 432, 173 (2004).

41. Crouse, J., Xu, H. C., Lang, P. A. \& Oxenius, A. NK cells regulating T cell responses: mechanisms and outcome. Trends Immunol. 36, 49-58 (2015)

42. Mailliard, R. B. et al. Dendritic cells mediate NK cell help for Th1 and CTL responses: two-signal requirement for the induction of $\mathrm{NK}$ cell helper function. J. Immunol. 171, 2366-2373 (2003)

43. Crispe, I. N. Immune tolerance in liver disease. Hepatology 60, 2109-2117 (2014).

44. Manns, M. P. et al. Hepatitis C virus infection. Nat. Rev. Dis. Prim. 3, 17006 (2017).

45. Zuniga, E. I., Macal, M., Lewis, G. M. \& Harker, J. A. Innate and adaptive immune regulation during chronic viral infections. Annu. Rev. Virol. 2, 573-597 (2015).

46. Donnelly, R. P., Dickensheets, H. \& O’Brien, T. R. Interferon-lambda and therapy for chronic hepatitis $\mathrm{C}$ virus infection. Trends Immunol. 32, 443-450 (2011).

47. Crotta, S. et al. Inhibition of natural killer cells through engagement of CD81 by the major hepatitis C virus envelope protein. J. Exp. Med. 195, 35-41 (2002).

48. Tseng, C. T. \& Klimpel, G. R. Binding of the hepatitis C virus envelope protein E2 to CD81 inhibits natural killer cell functions. J. Exp. Med. 195, 43-49 (2002).

49. Yoon, J. C., Yang, C. M., Song, Y. \& Lee, J. M. Natural killer cells in hepatitis C: current progress. World J. Gastroenterol. 22, 1449-1460 (2016).

50. Herzer, $K$. et al. Upregulation of major histocompatibility complex class I on liver cells by hepatitis $\mathrm{C}$ virus core protein via p53 and TAP1 impairs natural killer cell cytotoxicity. J. Virol. 77, 8299-8309 (2003).

51. Cavanaugh, V. J., Raulet, D. H. \& Campbell, A. E. Upregulation of CD94/ NKG2A receptors and Qa-1b ligand during murine cytomegalovirus infection of salivary glands. J. General. Virol. 88, 1440-1445 (2007).

52. Prabhakaran, K. et al. Sensory neurons regulate the effector functions of CD8 $+\mathrm{T}$ cells in controlling HSV-1 latency ex vivo. Immunity 24, 657 (2006).

53. Ramsuran, V. et al. Elevated HLA-A expression impairs HIV control through inhibition of NKG2A-expressing cells. Science 359, 86-90 (2018).

54. André, P. et al. Anti-NKG2A mAb is a checkpoint inhibitor that promotes antitumor immunity by unleashing both T and NK cells. Cell 175, 1731-1743.e13 (2018).

55. van Montfoort, N. et al. NKG2A blockade potentiates CD8 T cell immunity induced by cancer vaccines. Cell 175, 1744-1755.e15 (2018).

56. Waggoner, S. N., Cornberg, M., Selin, L. K. \& Welsh, R. M. Natural killer cells act as rheostats modulating antiviral T cells. Nature 481, 394-398 (2012).

57. Waggoner, S. N., Daniels, K. A. \& Welsh, R. M. Therapeutic depletion of natural killer cells controls persistent infection. J. Virol. 88, 1953-1960 (2014).

58. Boni, C. et al. Restored function of HBV-specific $\mathrm{T}$ cells after long-term effective therapy with nucleos $(\mathrm{t})$ ide analogues. Gastroenterology 143, 963-973.e969 (2012)

59. Boni, C. et al. Natural killer cell phenotype modulation and natural killer/Tcell interplay in nucleos $(\mathrm{t})$ ide analogue-treated hepatitis e antigen-negative patients with chronic hepatitis B. Hepatology 62, 1697-1709 (2015).

60. Pallmer, K. \& Oxenius, A. Recognition and regulation of T cells by NK cells. Front. Immunol. 7, 251 (2016).
61. Zhang, Q. et al. Blockade of the checkpoint receptor TIGIT prevents NK cell exhaustion and elicits potent anti-tumor immunity. Nat. Immunol. 19, 723-732 (2018).

62. Simmons, B., Saleem, J., Hill, A., Riley, R. D. \& Cooke, G. S. Risk of late relapse or reinfection with hepatitis $\mathrm{C}$ virus after achieving a sustained virological response: a systematic review and meta-analysis. Clin. Infect. Dis. 62, 683-694 (2016).

63. Grebely, J., Hajarizadeh, B. \& Dore, G. J. Direct-acting antiviral agents for HCV infection affecting people who inject drugs. Nat. Rev. Gastroenterol. Hepatol. 14, 641 (2017).

64. Callendret, B. et al. T-cell immunity and hepatitis $\mathrm{C}$ virus reinfection after cure of chronic hepatitis $\mathrm{C}$ with an interferon-free antiviral regimen in a chimpanzee. Hepatology 60, 1531-1540 (2014).

65. Guillerey, C., Huntington, N. D. \& Smyth, M. J. Targeting natural killer cells in cancer immunotherapy. Nat. Immunol. 17, 1025 (2016)

66. Han, Q. et al. Compensatory mutations in NS3 and NS5A proteins enhance the virus production capability of hepatitis C reporter virus. Virus Res. 145, 63-73 (2009).

67. Zhong, J. et al. Persistent hepatitis $\mathrm{C}$ virus infection in vitro: coevolution of virus and host. J. Virol. 80, 11082-11093 (2006).

68. Watanabe, H. et al. Details of an isolation method for hepatic lymphocytes in mice. J. Immunol. Methods 146, 145-154 (1992).

69. Zhang, C. et al. Comprehensive mapping of antigen specific $\mathrm{T}$ cell responses in hepatitis $\mathrm{C}$ virus infected patients with or without spontaneous viral clearance. PLoS ONE 12, e0171217 (2017).

\section{Acknowledgements}

We thank Drs. Zhong-jun Dong (Institute for Immunology and School of Medicine, Tsinghua University) and Fu-sheng Wang (Treatment and Research Center for Infectious Diseases, Beijing 302 Hospital) for the insightful critics of the manuscript. We also thank Dr. Peng-yan Xia (Institute of Biophysics, Chinese Academy of Sciences) for help on NK killing assay and Zhi-yong Zhuo (Institute of Biophysics, Chinese Academy of Sciences) for breeding and genotyping of transgenic mice. This work was supported in part by grants from the National Natural Sciences Foundation of China to H.T. (31621061 and 81530067) and H.-r.C. (31700786); the National Basic Research Program of China to J.-q.N. (2015CB554300) and C.Z. (2015CB554303); and CAS to H.T. (QYZDJ-SSW-SMC026, 153831KYSB20160038, and XDB2903000).

\section{Author contributions}

H.T. conceived the study. C.Z., H.-r.C. and X.-m.W. designed and performed experiments and analyzed data. S.-r.L., W.-h.W., S.-y.Z., S.-f.W. and J.-z.C. performed experiments and analyzed data. T.T., X.J., Y.-z.W., X.-w.C., S.-d.W. and J.-q.N. helped experiment designs and discussed the data. H.T., H.-r.C. and C.Z. drafted and revised the manuscript.

\section{Additional information}

Supplementary Information accompanies this paper at https://doi.org/10.1038/s41467019-09212-y.

Competing interests: The authors declare no competing interests.

Reprints and permission information is available online at http://npg.nature.com/ reprintsandpermissions/

Journal peer review information: Nature Communications thanks Mario Mondelli and Paul Klenerman for their contribution to the peer review of this work. Peer reviewer reports are available.

Publisher's note: Springer Nature remains neutral with regard to jurisdictional claims in published maps and institutional affiliations.

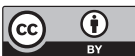

Open Access This article is licensed under a Creative Commons Attribution 4.0 International License, which permits use, sharing, adaptation, distribution and reproduction in any medium or format, as long as you give appropriate credit to the original author(s) and the source, provide a link to the Creative Commons license, and indicate if changes were made. The images or other third party material in this article are included in the article's Creative Commons license, unless indicated otherwise in a credit line to the material. If material is not included in the article's Creative Commons license and your intended use is not permitted by statutory regulation or exceeds the permitted use, you will need to obtain permission directly from the copyright holder. To view a copy of this license, visit http://creativecommons.org/ licenses/by/4.0/

(c) The Author(s) 2019 